\title{
Very high stratospheric influence observed in the free troposphere over the northern Alps - just a local phenomenon?
}

\author{
Thomas Trickl $^{1}$, Hannes Vogelmann ${ }^{1}$, Ludwig Ries $^{2}$, and Michael Sprenger ${ }^{3}$ \\ ${ }^{1}$ Karlsruher Institut für Technologie, Institut für Meteorologie und Klimaforschung, IMK-IFU, \\ Kreuzeckbahnstr. 19, 82467 Garmisch-Partenkirchen, Germany \\ ${ }^{2}$ Umweltbundesamt II 4.5, Plattform Zugspitze, GAW-Globalobservatorium Zugspitze-Hohenpeißenberg, \\ Schneefernerhaus, 82475 Zugspitze, Germany \\ ${ }^{3}$ Eidgenössische Technische Hochschule (ETH) Zürich, Institut für Atmosphäre und Klima, \\ Universitätstraße 16, 8092 Zürich, Switzerland
}

Correspondence: Thomas Trickl (thomas.trickl@kit.edu, thomas@trickl.de)

Received: 19 June 2019 - Discussion started: 12 August 2019

Revised: 20 November 2019 - Accepted: 2 December 2019 - Published: 6 January 2020

\begin{abstract}
The atmospheric composition is strongly influenced by a change in atmospheric dynamics, which is potentially related to climate change. A prominent example is the doubling of the stratospheric ozone component at the Zugspitze summit station (2962 ma.s.l., GarmischPartenkirchen, Germany) between the mid-seventies and 2005 , roughly from 11 to $23 \mathrm{ppb}$ (43\%). Systematic efforts for identifying and quantifying this influence have been made since the late 1990s. Meanwhile, routine lidar measurements of ozone and water vapour carried out at GarmischPartenkirchen (German Alps) since 2007, combined with in situ and radiosonde data and trajectory calculations, have revealed that stratospheric intrusion layers are present on $84 \%$ of the yearly measurement days. At Alpine summit stations the frequency of intrusions exhibits a seasonal cycle with a pronounced summer minimum that is reproduced by the lidar measurements. The summer minimum disappears if one looks at the free troposphere as a whole. The mid- and uppertropospheric intrusion layers seem to be dominated by very long descent on up to hemispheric scale in an altitude range starting at about $4.5 \mathrm{~km}$ a.s.l. Without interfering air flows, these layers remain very dry, typically with $\mathrm{RH} \leq 5 \%$ at the centre of the intrusion. Pronounced ozone maxima observed above Garmisch-Partenkirchen have been mostly related to a stratospheric origin rather than to long-range transport from remote boundary layers. Our findings and results for other latitudes seem to support the idea of a rather high contribu-
\end{abstract}

tion of ozone import from the stratosphere to tropospheric ozone.

\section{Introduction}

For many years the pronounced rise of tropospheric ozone due to growing anthropogenic air pollution has been the subject of intensive research. The background level of ozone has reached $50 \mathrm{ppb}$ and more at some sites at the northern midlatitudes (e.g. Parrish et al., 2012; Gaudel et al, 2018). However, megacity ozone may reach even several hundred ppb (e.g. Parrish et al., 2011, 2016) that may ultimately contribute to the tropospheric ozone background.

On the other hand, the most important natural source of tropospheric ozone, i.e. the import from the stratosphere, has been frequently related to the Montsouris value of just about $10 \mathrm{ppb}$ estimated for the late 19th century (Volz and Kley, 1987). Layers of stratospheric air can be identified directly based on criteria like elevated ozone and low humidity. This direct import in deep stratospheric air intrusions has long resulted in estimates of the stratospheric influence on the tropospheric ozone level of about $10 \%$ and less (e.g. Elbern et al., 1997; Beekmann et al., 1997; Stohl et al., 2000). This would suggest a rather small relative importance of stratosphere-totroposphere transport (STT), with some uncertainty originating from the "indirect" stratospheric component that cannot 
be detected due to complete mixing of the stratospheric intrusions into the troposphere.

Quantifying STT has been attempted for more than half a century. Whereas early studies aimed at identifying the STT mechanisms (e.g. Danielsen, 1968), more recent work has also estimated the STT budget by extrapolations of observational data (e.g. Danielsen and Mohnen, 1977; Viezee et al., 1983; Beekmann et al., 1997) or by diagnosing the crosstropopause transport by global and regional weather and climate models (e.g. Roelofs and Lelieveld, 1997; Kentarchos and Roelofs, 2003; Stevenson et al., 2006; Wild, 2007; Young et al., 2013). Model-based approaches have frequently concentrated on the overall exchange rate (for STE) rather than on that for STT. In the most recent multi-model comparison (Young et al., 2013) the models agree within about $\pm 20 \%$ (standard deviation) around an average net STE rate of $477 \mathrm{Tg} \mathrm{a}^{-1}$. This value, obtained as a difference of the steady-state photochemical production rate and the loss rates, is just about $10 \%$ of the production rate. The ozone mixing ratio due to STT was e.g. obtained from semi-Lagrangian approaches such as by Roelofs and Lelieveld (1997) or Collins et al. (2003). Roelofs and Lelieveld (1997) found a fraction due to STT of $40 \%$ in tropospheric ozone. This value looks rather high given the coarse resolution of the underlying chemistry-transport model of (e.g. horizontally) $3.75^{\circ} \times 3.75^{\circ}$ that is insufficient for resolving thin stratospheric layers in the troposphere (see Roelofs et al., 2003; Rastigejev et al., 2010; Easthman and Jacobs, 2017). The stratospheric contributions of Collins et al. (2003) are lower (roughly $30 \%$ above mid-latitude sites, the average mixing ratio typically rising from 40 to $60 \mathrm{ppb}$ from the lower to upper troposphere) and vary from site to site. In a study with higher spatial resolution, Jaeglé et al. (2017) examined STT in dry intrusions associated with extratropical cyclones. They found that, on average, $15 \%$ of the ozone mass in a dry intrusion is irreversibly mixed into the troposphere.

In principle, a quantification of STT should involve observations. However, determining the STT flux from observations is a highly demanding task. Assessments from observations are easier for STT than for TST (troposphere-tostratosphere transport) since both ozone and water vapour are suitable complementary tracers. The results strongly depend on the criteria selected for data filtering based on tracers such as $\mathrm{O}_{3}, \mathrm{H}_{2} \mathrm{O}$ or ${ }^{7} \mathrm{Be}$ (e.g. Stohl et al., 2000). In addition, mixing of the dry descending layers with tropospheric air must be taken into account, which was, however, recently found to be much less severe than previously thought (Trickl et al., 2014, 2016).

Gradually, STT has turned out to be potentially much more important than concluded from the early assessments. For instance, a correlation study of $\mathrm{O}_{3}$ and $\mathrm{H}_{2} \mathrm{O}$ based on vertical profiles derived from aircraft ascents and descents in the vicinity of airports within the MOZAIC (Measurement of Ozone, Water Vapour by Airbus In-Service Aircraft, Marenco et al., 1998) project revealed a rich ("ubiquitous") layer structure in the free troposphere (Newell et al., 1998; Thouret et al., 2000). The layers were identified by positive or negative departures from the mean background. The layers with excess ozone and reduced water vapour clearly dominate, with about $50 \%$ of the cases in all regions. Although the threshold for relative humidity drops applied $(5 \%)$ is much lower than needed for verifying STT (Trickl et al., 2014, 2015), this high fraction is a hint towards significant downward transport. The occurrence of dry layers with elevated ozone maximizes between 4 and $6 \mathrm{~km}$.

The global distribution of tropopause folds is rather inhomogeneous with maxima in regions around the jet streams (e.g. James et al., 2003; Sprenger et al., 2003; Škerlak et al., 2014)). Sprenger et al. (2003) found that the role of the subtropical jet stream (STJ) for STT had been strongly underestimated. The STJ persists during most of the year (Koch et al., 2006) and, thus, could be associated with frequent vertical exchange. However, it is not only the persistence that matters: high ozone values have also been reported in subtropical intrusions. For example, very strong ozone signatures in the troposphere exceeding $200 \mathrm{ppb}$ have been detected over northern India (Ojha et al., 2014, 2017). High ozone values in the middle and upper troposphere from regions next to the STJ have even been observed above Garmisch-Partenkirchen (Germany) after transport almost all the way around the Northern Hemisphere (six cases: Trickl et al., 2011; see also Langford, 1999). In general, observations at the source latitudes have been limited (e.g. Gouget et al., 1996; Cammas et al., 1998; Kowol-Santen and Ancellet, 2000; Zachariasse, 2000; Zahn et al., 2002). Beyond the regions around the STJ, STT has been found in the tropics. For example, during $30 \%$ of the MOZAIC flights across the tropical Atlantic at least one event with more than $100 \mathrm{ppb}$ of ozone occurred, which was associated with strong convection in the Inter-Tropical Convergence Zone (Suhre et al., 1997).

A great surprise was the detection of a substantial stratospheric influence at the Zugspitze mountain-top site ( $2962 \mathrm{~m}$ a.s.l.) in the German Alps and its pronounced positive trend (Fig. 1). In assessments of long-term ozone series the Zugspitze $\mathrm{O}_{3}$ exhibited the strongest increase (e.g. Parrish et al., 2012; Logan et al., 2012; Oltmans et al., 2012). The Zugspitze ozone increased from 1978 to 2003, in contrast to the neighbouring Wank site (1780 m a.s.1.), where the annual-average ozone level has remained constant since the 1980s. We have explained (Trickl et al., 2010) the difference between Zugspitze and Wank ozone by a much larger amount of stratospheric air reaching the higher of the two summits (e.g. Elbern et al., 1997).

The positive trend of stratospheric influence is seen in the contributions of both the "direct" descent to the Zugspitze summit, characterized by distinct ozone and humidity structures, and the "indirect" contribution of aged stratospheric intrusions strongly mixed with the surrounding tropospheric air (Fig. 1). The direct contribution $(<10 \%)$ was obtained from correlating low humidity with elevated ${ }^{7} \mathrm{Be}$ (Scheel, 


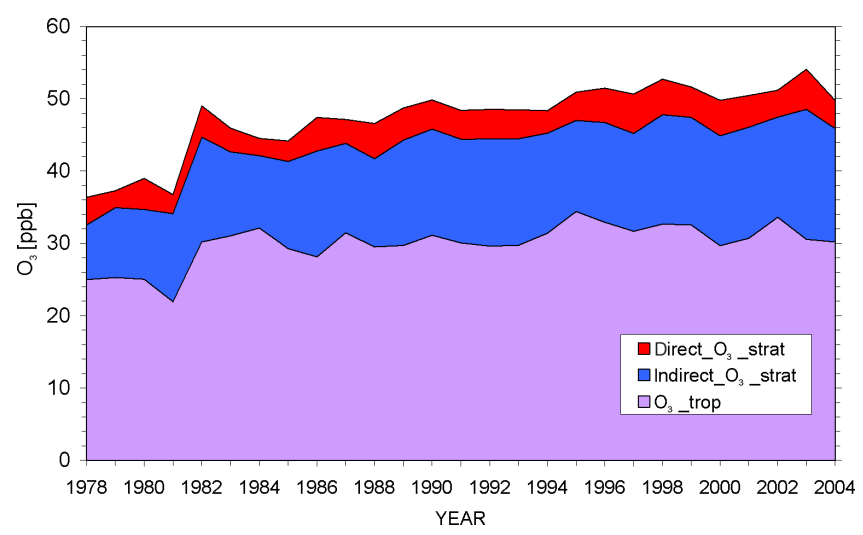

Figure 1. Annual mean ozone mixing ratios for the Zugspitze summit from 1978 to 2003, together with preliminary estimates of the directly detected stratospheric component (red) and of the indirect component (blue) obtained from ${ }^{7} \mathrm{Be}$ measurements: the stratospheric influence doubled during that period. As a consequence after 1981 the positive ozone trend disappears after subtracting the evaluated stratospheric fraction of ozone. The figure of $\mathrm{H}$. E. Scheel is taken from the ATMOFAST final report (2005; Fig. 2.40 on p. 67).

2003, pp. 66-71 in ATMOFAST, 2005). Aged stratospheric air masses that are completely mixed into the troposphere cannot be identified by data filtering and, therefore, had not been derived in studies based on observations. In order to obtain some guess of the indirect component of STT in the Zugspitze ozone, Scheel (in ATMOFAST, 2005) determined a ${ }^{7}$ Be-to-ozone conversion factor from the direct component, considering that $2 / 3$ of ${ }^{7} \mathrm{Be}$ is produced in the stratosphere (Lal and Peters, 1967). The results in Fig. 1 are associated with an uncertainty of unknown magnitude, in part because of the limited decay time of ${ }^{7} \mathrm{Be}(53.42 \mathrm{~d}( \pm 0.01 \mathrm{~d})$; Huh and Liu, 2000). However, they are plausible since the 1978 stratospheric fraction of $11.3 \mathrm{ppb}(31.2 \%)$ is in the expected range of values derived from measurement in the late 19th century (Volz and Kley, 1988; Marenco et al., 1994). From the decline of the ozone precursors over Europe in the 1990s (e.g. Jonson et al., 2006; Vautard et al., 2006), one would expect a negative development. Thus, the estimate of the stratospheric component is perhaps even somewhat conservative (see Tarasick et al., 2019a, for a more thorough discussion of possibly higher pre-industrial ozone levels).

A comparable positive ozone trend is also reported for the Swiss Jungfraujoch station ( $3580 \mathrm{~m}$ a.s.l.) where the ozone measurements started in 1992 (Ordoñez et al., 2007). For the lower-lying Italian station Monte Cimone (2165 m a.s.1.), no significant correlation between ozone and the intrusion frequency was detected. However, this conclusion is only based on the years 1996 to 2011, i.e. for a time period that is rather late compared with the ozone rise at the Alpine sites (Cristofanelli et al., 2015). Finally, Colette and Ancellet (2005) retrieved an increase in stratospheric ozone in the entire tropo- sphere over Europe back to 1970 from the analysis of longterm ozonesonde data. Central Europe is located at the exit of the North Atlantic storm track and, therefore, is a receptor region for subsiding stratospheric layers. A possible explanation of the positive trend in our view could be a reaction of the atmospheric dynamics to climate change (see also Collins et al., 2003; Yang et al., 2016; Lin et al., 2015; Neu et al., 2014).

Dibb et al. (2003) determined the latitudinal distribution of STT over North America by a total of 39 air-chemistry aircraft missions from Boulder (Colorado, USA, $40^{\circ} \mathrm{N}$ ) to up to $86^{\circ} \mathrm{N}$. The altitude varied between the surface and about $7000 \mathrm{~m}$. These flights were special since also here ${ }^{7} \mathrm{Be}$ filter samples were taken as an additional indicator of stratospheric air, an advantage which is normally limited to surface sites. Stratospheric influence was identified on 23 of the flights, most of the intrusions being detected near and above $6 \mathrm{~km}$. Above $6 \mathrm{~km}$ the flights took place in stratospheric air during more than half of the time, indicating an extreme transfer of ozone in that altitude range. Below $50^{\circ} \mathrm{N}$ the stratospheric layers were limited to this altitude range.

The seasonal cycle of the stratospheric ozone contribution at Alpine summit stations exhibits a pronounced summer minimum (Elbern et al, 1997; Stohl et al., 2000; Trickl et al., 2010). In contrast to this, Beekmann et al. (1997) concluded for the entire free troposphere above three European ozonesonde stations a seasonal cycle with a slight summer maximum, based on data filtering of ozone profiles between 1969 and 1994. A transition to this behaviour is indicated for growing altitude of the Alpine stations: the summer minimum is least pronounced at the highest of the stations previously compared, Jungfraujoch (see Fig. 1 of Trickl et al., 2010).

Motivated by all these findings, we extend in this paper our STT studies to the full free troposphere. The analysis is based on routine lidar measurements of ozone, water vapour and aerosol since 2007, as well as radiosonde relative humidity and transport modelling. The resulting stratospheric component in tropospheric ozone over central Europe is surprisingly strong. We see some confirmation of our findings in recent lidar and sonde results from lower latitudes which will be discussed in detail in Sect. 4 .

After introducing the observational methods and the models used in Sect. 2, we describe the data selection approach for STT events (Sect. 3.1). In Sects. 3.2 and 3.3 we give typical examples for the most important intrusion types and discuss the role of STT during the warm season in comparison with long-range transport of high ozone advected from remote pollution events by intercontinental transport. Section 3 describes the details of the statistical analysis of the fraction of STT days 2007-2016. Finally, an overall discussion and conclusions are given in Sect. 4. 


\section{Methods}

\subsection{Measurements}

\subsubsection{IFU ozone DIAL}

The tropospheric ozone lidar is operated in GarmischPartenkirchen, Germany, at IMK-IFU (formerly IFU; $47^{\circ} 28^{\prime} 37^{\prime \prime} \mathrm{N}, 11^{\circ} 3^{\prime} 52^{\prime \prime} \mathrm{E}$; $740 \mathrm{~m}$ a.s.l.). The laser source is a Raman-shifted $\mathrm{KrF}$ laser, and two separate receiving telescopes are used to divide the dynamic range of the backscatter signal of roughly 8 decades. This lidar was completed as a two-wavelength differential-absorption lidar (DIAL) in 1990 (Kempfer et al., 1994) and a first annual sounding series was achieved in 1991 (Carnuth et al., 2002). It was upgraded to a three-wavelength DIAL in 1994 and 1995 (Eisele and Trickl, 1997), leading to a unique vertical range between roughly $0.25 \mathrm{~km}$ above the ground and 3 to $5 \mathrm{~km}$ above the tropopause, the measurement time interval being just $41 \mathrm{~s}$. By comparing the ozone profiles retrieved from different wavelength combinations (e.g. $277-313 \mathrm{~nm}$ or $292-$ $313 \mathrm{~nm}$ ), an internal quality check is possible. The choice of an "on" wavelength below $280 \mathrm{~nm}$ is particularly beneficial for achieving a high accuracy and a high vertical resolution (up to about $5 \mathrm{~km}$ above the ground). Density has been converted to mixing ratio by using pressure and temperature data from nearby radiosonde stations (Sect. 2.1.4).

The noise level of the system since late 2012 is $\pm 1 \times 10^{-6}$ of the input voltage range of the digitizer system. The DIAL features low uncertainties of about $\pm 2 \mathrm{ppb}$ in the lower free troposphere, approximately tripling (under optimum conditions) in the upper troposphere because of the use of the 292-313 nm wavelength pair. Comparisons with the nearby Zugspitze in situ measurements (at $2962 \mathrm{~m}$ a.s.l.; see below) show no relevant mutual bias, the standard deviation of the differences being less than $2 \mathrm{ppb}$. The uncertainty further diminished after another system upgrade in 2012, after introducing a new ground-free input stage to our transient digitizers (Licel) that reduced the noise level by roughly a factor of 3 . For the range covered by the near-field receiver (below $1.2 \mathrm{~km}$ above the lidar), the uncertainty is of the order of $\pm 5 \mathrm{ppb}$. The upper-tropospheric performance may be degraded in the presence of high lower-tropospheric ozone concentrations absorbing a lot of the ultraviolet laser emission and by enhanced sky light in summer, in particular in the presence of clouds. The vertical resolution is dynamically varied between $50 \mathrm{~m}$ and a few hundred metres, depending on the signal-to-noise ratio decreasing with altitude. Within stratospheric intrusion layers the vertical smoothing is reduced as far as possible in order to avoid a reduction of the peak concentrations by smoothing. The lidar has been used in numerous atmospheric transport studies (e.g. Eisele et al., 1999; Stohl and Trickl, 1999; Trickl et al., 2003; and other publications cited in this paper).
Aerosol backscatter profiles with a very good signal-tonoise ratio up to the lower stratosphere are obtained from the $313 \mathrm{~nm}$ "off" channel of the lidar. The methods, implying an ozone correction, have been described by Eisele and Trickl (2005). Examples demonstrating the data quality achieved in recent years (maximum noise level of the backscatter coefficients $\pm 1 \times 10^{-7} \mathrm{~m}^{-1} \mathrm{sr}^{-1}$, reached in the tropopause region) can be seen in Trickl et al. (2015). We derive vertical profiles of the aerosol backscatter coefficients based on a constant backscatter-to-extinction ratio of $0.020 \mathrm{sr}^{-1}$, which is the average value derived within the European Aerosol Research Lidar Network (EARLINET, 2003). Within clouds larger values are taken, if possible optimized for minimum discrepancy of the backscatter profiles below and above the cloud.

\subsubsection{IFU water-vapour DIAL at the Schneefernerhaus high-altitude station}

The Zugspitze water-vapour DIAL is operated at the Schneefernerhaus high-altitude research station (UFS, $47^{\circ} 25^{\prime} 00^{\prime \prime} \mathrm{N}, 10^{\circ} 58^{\prime} 46^{\prime \prime} \mathrm{E}$ ) at $2675 \mathrm{~m}$ a.s.l., about $8.5 \mathrm{~km}$ to the south-west of IMK-IFU (Garmisch-Partenkirchen, Germany), and $0.5 \mathrm{~km}$ to the south-west of the Zugspitze summit. The full details of this lidar system were described by Vogelmann and Trickl (2008). It is based on a powerful tunable narrow-band $\mathrm{Ti}$ : sapphire laser system with up to $250 \mathrm{~mJ}$ energy per pulse operated at about $817 \mathrm{~nm}$ and a $0.65-\mathrm{m}-$ diameter Newtonian receiver. Due to these specifications a vertical range up to about $12 \mathrm{~km}$ can be reached, almost unaffected by daylight. However, mostly the laser has been operated at half the maximum pulse energy or less to extend the life time of the high-voltage components such as flashlamps. A separation of near-field and far-field signals is achieved by a combination of a beam splitter and a blade in the farfield channel. The operating range starts below the altitude of the summit station ( $2962 \mathrm{~m}$ a.s.l.). The electronics are almost identical to those of the ozone DIAL. However, at the operating wavelength of $817 \mathrm{~nm}$ avalanche photodiodes have been used that introduce higher noise than the photomultiplier tubes preferred for shorter wavelengths. Thus, the system has not yet reached its expected optimum performance in the upper troposphere.

The vertical resolution chosen in the data evaluation is dynamically varied between $50 \mathrm{~m}$ in altitude regions with a good signal-to-noise ratio and roughly $350 \mathrm{~m}$ in the upper troposphere. Free-tropospheric measurements during dry conditions clearly benefit from the elevated site outside or just below the edge of the moist Alpine boundary layer (e.g. Carnuth and Trickl, 2000; Nyeki et al., 2000; Carnuth et al., 2002). After a few years of testing, validating and optimizing the system, routine measurements started in January 2007 with typically 2 measurement days per week, provided that the weather conditions were favourable. Operation has been 
interrupted since winter 2015 due to fatal laser damage. A new $\mathrm{Ti}$ : sapphire laser system is under development.

The lidar has been validated in several comparisons with local and remote radiosonde ascents (Vogelmann and Trickl, 2008), an airborne DIAL (Trickl et al., 2016) and the Zugspitze Fourier transform spectrometer (Vogelmann et al., 2011). A noise level of $5 \%$ and a bias of $1 \%$ at most was verified to altitudes of more than $6 \mathrm{~km}$. Furthermore, a very high importance of volume matching in comparisons of watervapour profiling instruments was found (Vogelmann et al., 2011, 2015), on the scale of a quarter of an hour and a few kilometres.

In some cases, in which a direct comparison of the exact matching of the humidity and aerosol layers was necessary (e.g. Trickl et al., 2016), aerosol backscatter coefficients were retrieved from the "off" wavelength channel. The calculations were done with a program developed for the IFU aerosol lidar systems (e.g. Trickl et al., 2013; Wandinger et al., 2016).

\subsubsection{In situ measurements at the Zugspitze summit and at the Schneefernerhaus station (UFS)}

In addition, in situ data from the monitoring station at the Zugspitze summit (air inlet: $2962 \mathrm{~m}$ a.s.l.) have been inspected, namely ozone and relative humidity. Ozone was measured between 1978 and 2012 (e.g. Reiter et al., 1987; Scheel et al., 1997; Oltmans et al., 2006, 2012; Logan et al., 2012; Parrish et al., 2012). At present the data have been evaluated until 2010. The relative uncertainty of the Zugspitze ozone is $1 \%$. Ultraviolet absorption instruments have been employed (Thermo Electron Corporation, USA, TE49 analysers). Relative humidity (RH) was registered with a dewpoint mirror (Thygan VTP6, Meteolabor, Switzerland) with a quoted uncertainty below $5 \%$ RH. However, the instrument has a wet bias of almost $10 \%$ under very dry conditions (Trickl et al., 2014). The Zugspitze in situ measurements were discontinued in January 2013. The data for the final 2 years have not been evaluated.

After 2010 we have used the corresponding data of the Global Atmosphere Watch (GAW) observatory at the Schneefernerhaus research station (UFS; see $\mathrm{H}_{2} \mathrm{O}$ lidar), operated by the German Umweltbundesamt (UBA, i.e. Federal Environmental Agency; $47^{\circ} 25^{\prime} 0^{\prime \prime} \mathrm{N}, 11^{\circ} 58^{\prime} 46^{\prime \prime} \mathrm{E}$; air inlet at $2670 \mathrm{~m}$ a.s.l.). Ozone is continuously measured by ultraviolet (UV) absorption at $254 \mathrm{~nm}$ (Thermo Electron Corporation, model Ts49i). Relative humidity is monitored by the German Weather Service with an EE33 humidity sensor (E+E Elektronik). The calibration of the UBA instrumentation is routinely verified as part of the GAW quality assurance efforts. The instruments are controlled daily and serviced on all regular work days.

For the comparisons shown in the figures of this paper we use time averages of up to $1 \mathrm{~h}$ because of the time delay of the air mass between UFS and IFU. The comparisons of ozone DIAL and UFS are highly satisfactory, with differences mostly staying below $2 \mathrm{ppb}$. However, orographic air-mass lifting must be taken into account that can lead to vertical displacements of ozone structures and larger differences between lidar and in situ data.

\subsubsection{Sonde data}

Radiosonde data are routinely used for calculating the atmospheric density, which is necessary for quantitative aerosol retrievals and the conversion of the ozone or the watervapour number density to mixing ratio. Most importantly, on each measurement day of the ozone DIAL the presence of dry and moist layers was examined in order to identify potential advection from a remote stratosphere or (marine) boundary layer, respectively. The sonde measurements overlapped with the measurements of the water-vapour DIAL until 2014 and helped to fill gaps in the DIAL schedule. After 2014, when the DIAL was damaged, they were exclusively used. The sonde data have been imported from the University of Wyoming database (http://weather.uwyo.edu/ upperair/sounding.html, last access: 2 January 2020). Preferentially, the Oberschleißheim ("Munich") sonde RH has been examined, this station (number: 10868) being located $100 \mathrm{~km}$ roughly to the north of IFU. It turned out that on most STT days at least one intrusion was present in both the sonde and the IFU and UFS DIAL profiles, just slightly shifted in altitude. If data were not available for a given standard launch time or if no indication of an intrusion was found, $\mathrm{RH}$ profiles from other surrounding stations were used, such as Stuttgart (10 739, about $200 \mathrm{~km}$ to the north-west), Payerne $(06610$, about $310 \mathrm{~km}$ to the west), or Innsbruck $(11120,32 \mathrm{~km}$ to the south, one measurement per day only). The station choice was also based on the trajectory results (Sect. 2.2), and sometimes even more remote sites have been inspected.

The sonde type used by the German Weather Service (DWD, Deutscher Wetterdienst) during the period presented here was RS 92 (Vaisala; e.g. Miloshevich et al., 2006; Steinbrecht et al., 2008). The sonde data feature an artificial cutoff at $1 \%$ for conditions when the UFS DIAL revealed even much drier conditions (Trickl et al., 2014).

\subsection{Transport modelling}

\subsubsection{LAGRANTO}

Four-day forward trajectories have been calculated since September 2000 once a day for start times $t_{0}=01: 00 \mathrm{CET}$ $($ Central European Time $=\mathrm{UTC}+1 \mathrm{~h}), t_{0}+12 \mathrm{~h}, t_{0}+14 \mathrm{~h}$ and $t_{0}+36 \mathrm{~h}$ based on the Lagrangian Analysis Tool (LAGRANTO; Wernli and Davies, 1997; Sprenger and Wernli, 2015; http://www.lagranto.ethz.ch, last access: 2 January 2020). On each day, trajectories are calculated using operational forecast data from the European Centre for Medium-Range Weather Forecasts (ECMWF) interpolated 
to a longitude-latitude grid with $1^{\circ} \times 1^{\circ}$ horizontal resolution. With respect to the vertical levels, ECMWF has used 137 vertically hybrid levels since June 2013 (and 91 levels before), where 24 levels are between 250 and 600 mbar. For each start time the $4 \mathrm{~d}$ forward trajectories are calculated starting in the entire region covering the Atlantic Ocean and western Europe $\left(20^{\circ}\right.$ east to $80^{\circ}$ west and 40 to $80^{\circ}$ north) between 250 and $600 \mathrm{mbar}$. From this large set of trajectories those initially residing in the stratosphere (potential vorticity larger than $2.0 \mathrm{pvu}$ ) and descending during the following $4 \mathrm{~d}$ by more than 300 mbar into the troposphere were selected as "stratospheric intrusion trajectories". The same selection criterion was used in a previous case study (Wernli, 1997) to study an intrusion associated with a major North Atlantic cyclone.

Since June 2001 so-called "intrusion hit tables" have been additionally distributed that crudely estimate how stratospheric air develops over several days as a function of altitude above the four STACCATO (Stohl et al., 2003) partner stations Jungfraujoch, Zugspitze, Monte Cimone and Thessaloniki. Both the STT trajectories and the hit tables are distributed daily to all interested partners and institutions. Intrusion warnings based on these images have been issued by IFU if several of the stations could be affected (Zanis et al., 2003b).

For special case studies LAGRANTO has been operated with re-analysis meteorological data, for periods up to $5 \mathrm{~d}$ (e.g. Trickl, 2014, 2016). The three-dimensional wind fields for the calculation of the trajectories were taken from the ERA-Interim data set (Dee et al., 2011), which was interpolated to a $1^{\circ} \times 1^{\circ}$ horizontal grid and provides winds at $6 \mathrm{~h}$ intervals. The number of vertical levels in ERA-Interim is 60, with 11 levels between 250 and 600 mbar.

\subsubsection{HYSPLIT}

For analysing intrusion events with travel times exceeding the $4 \mathrm{~d}$ set in the operational LAGRANTO forecast runs or with source regions outside the domain of the forecasts, we use HYSPLIT (Hybrid Single-Particle Lagrangian Integrated Trajectory, Draxler and Hess, 1998; Stein et al., 2015; https://ready.arl.noaa.gov/HYSPLIT.php, last access: 2 January 2020) backward trajectories. HYSPLIT is easy to operate on the Internet and allows one to perform analyses of the vertical profiles with an adequate expenditure of time in an intense programme of vertical sounding. We mostly used the standard version with three trajectories initiated at different altitudes within or close to a layer of interest, selecting the "model vertical velocity" option (three-dimensional). These trajectories are extended over the maximum $315 \mathrm{~h}$. If necessary, several of these runs were started with slightly varying initial conditions. Multi-trajectory ensembles have also been used to create some "backward plume" (Trickl et al., 2013). However, these ensembles did not cover a sufficient number of days and have been applied in just a few case studies. HYSPLIT does not deliver potential vorticity. Thus, a substantial air-mass descent was looked for in order to identify a layer of stratospheric origin. If one or more trajectory bundles did not reach an altitude range typical of the lower stratosphere in the outflow region of an intrusion (e.g. roughly $7.5 \mathrm{~km}$ or more in boreal regions) within $315 \mathrm{~h}$, the case was rejected. Just in a few cases extension trajectories were calculated to verify the stratospheric source (Trickl et al., 2015). For some case studies the FLEXPART model has also been used with a time span of $20 \mathrm{~d}$ (Trickl et al., 2014). FLEXPART produces a much more complex output beyond the requirements of the current study, with thousands of measurements.

For many years we preferentially selected "reanalysis" meteorological data. Although the re-analysis data are coarser than other meteorological data available, they have led to a superior model performance in the free troposphere in many of our studies (Trickl et al., 2010, 2013, 2014; Fromm et al., 2010) and the analysis of our routine measurements. One additional example is discussed in Sect. 3.3. Despite the known limitations of backward trajectories (e.g. Stohl and Seibert, 1998), most specific free-tropospheric ozone or aerosol layers in years of observations could be related to reasonable sources, either in the boundary layer or in the stratosphere. Since 2014 near-real-time data evaluation and aerosol archiving in the EARLINET (European Aerosol Research Lidar Network, https://www.earlinet.org, last access: 2 January 2020) database have been achieved. Thus, GDAS-based trajectories (GDAS: Global Data Assimilation System) have been taken since the re-analysis-based model version are available only with considerable delay. The reanalysis mode was applied later on just if a GDAS run did not verify STT.

Slight vertical displacements of intrusion layers at the northern rim of the Alps exist in the model runs as reported previously (Trickl et al., 2010, 2015). These offsets, which vary from case to case, are explained by the insufficiently resolved orography that leads to an altitude of IMK-IFU (730 $\mathrm{m}$ a.s.l.) roughly half-way between the valley (Garmisch-Partenkirchen) and the Zugspitze summit. It is important to activate the check box "terrain" on the HYSPLIT input page together with the "AMSL" (above mean sea level) altitude option. In this case, the absolute height is used on the vertical axis and the contours of mountains are displayed, and better agreement with the altitude of an arriving atmospheric layer is achieved. The trajectories reproduce air-mass lifting above mountain ranges, which is particularly spectacular above Greenland, with a surface altitude of about $3 \mathrm{~km}$ maintained over hundreds of kilometres. 
Table 1. Measurement days with the ozone lidar between 2007 and 2016 (first line for a given year) and number of evaluated measurements for a given month (second line); sumd: the number of measurement days; summ: the number of evaluated measurements.

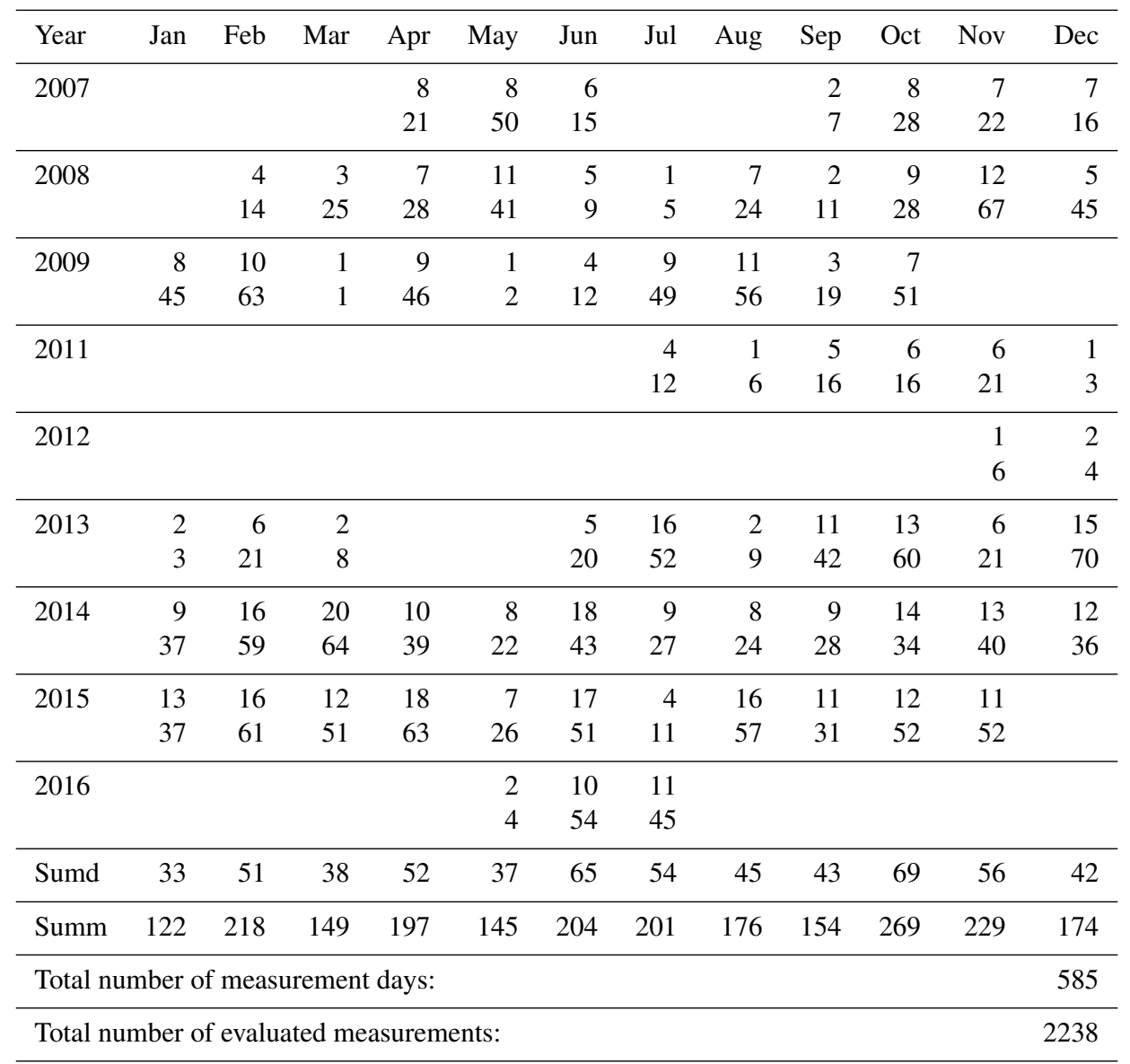

\section{Results}

\subsection{Description of the data analysis and interpretation}

In 2007, routine measurements have been started with both DIAL systems. This has yielded vertical profiles of ozone, water vapour and aerosol backscatter coefficients, derived from the $313 \mathrm{~nm}$ channel of the ozone DIAL. The number of measurements is particularly high in the case of the ozone lidar, resulting in a total of 2275 evaluated measurements on a total of $585 \mathrm{~d}$ between 2007 and 2016 (Table 1). The present study is, therefore, based on the ozone profiles during this period, and all other profile data are used for identifying the source for conspicuous ozone structures such as stratospheric air intrusions. Measurements have been made on a large number of fair-weather days or during short periods of clearing. However, really strong efforts to make at least one measurement were limited to the EARLINET (European Aerosol Research Lidar Network) "climatology days" Monday and Thursday (EARLINET, 2003). Ancillary information from sondes and trajectories has been gathered for each measurement day.
There are several gaps in the data of the ozone DIAL. These gaps are explained by extended periods of laser or computer damage, sometimes involving the search for new technical solutions for the system. The latest one occurred between August 2016 and September 2017. These large gaps do not exist for the water-vapour DIAL that was operated on $298 \mathrm{~d}$ between 2007 and the end of 2014. Despite the suboptimal temporal overlap of both DIAL systems there are 120 common measurement days during that period. On 108 of these days at least one intrusion was observed.

Ozone is not always a good tracer of STT. Particularly in winter, small exceedances of the background ozone level are frequently found in intrusion layers, related to a departure from the lowermost layer of the stratosphere. These exceedances can be resolved due to the high signal-to-noise ratio during the cold part of the year with low ozone ( $40 \mathrm{ppb}$ ) and the resulting moderate absorption of the $277 \mathrm{~nm}$ radiation.

For identifying stratospheric intrusions, we primarily looked for dry layers with $\mathrm{RH} \leq 10 \%$ (DIAL or sonde) even if there was just as just a small indication of an ozone rise. If ozone exceeded the neighbouring background by at 


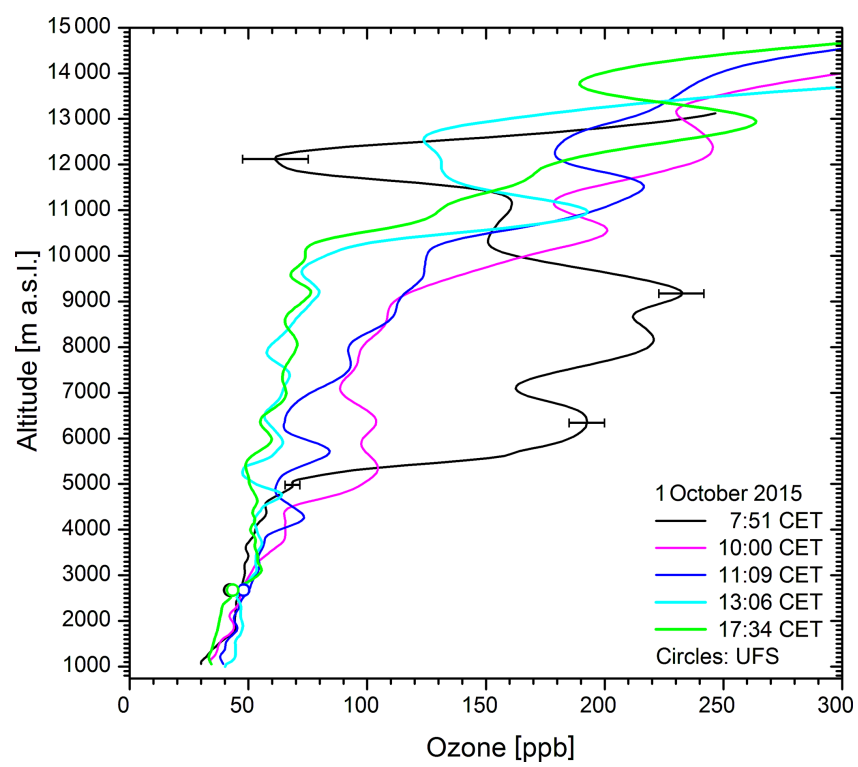

Figure 2. Vertical ozone profiles from the lidar measurements on 1 October $2015 ; 235 \mathrm{ppb}$ is the highest mixing ratio ever measured with the IFU DIAL since the beginning of the measurements in 1991. The distribution changes dramatically within about $10 \mathrm{~h}$. The Munich thermal tropopause level was $10454 \mathrm{~m}$ (00:00 UTC $=01: 00 \mathrm{CET})$ and $11903 \mathrm{~m}$ (12:00 UTC). The minimum sonde RH was $2 \%$ (00:00 UTC) and 1\% (cut-off level, 12:00 UTC). The in situ data ( $1 \mathrm{~h}$ averages) of UFS $(2670 \mathrm{~m})$ are marked with circles coded in the same colours as the lidar measurements next to the same time. A few error estimates representative of the respective altitudes are given for a judgement of the data quality.

least $10 \%$ we analysed the respective layer with both LAGRANTO forward and HYSPLIT backward trajectories as described in Sect. 2.2. Such tiny ozone peaks were extremely rare and, thus, almost did not affect the statistical results.

The choice of $\mathrm{RH}=10 \%$ as the $\mathrm{RH}$ threshold is reasonable since in most cases the minimum RH was clearly below this value. In confirmation of our results from the watervapour DIAL (Trickl et al., 2014, 2015, 2016), we found typical minimum $\mathrm{RH}$ values of $1 \%-3 \%$ in the sonde data for source regions over the North Atlantic or neighbouring regions (intrusion Types $1-5$ as defined by Trickl et al., 2010, mostly by distinguishing source regions), $1 \%$ being the lowest value found in the sonde listings (Sect. 2.1.4). For the most frequent long-range descent from a remote stratospheric source, e.g. central or western Canada, Alaska, or Siberia, Type 6 or slow descent from the North Atlantic minimum RH mostly ranged between $3 \%$ and $6 \%$. Interestingly, the reverse also holds: finding sonde RH values in this range very reliably points to very long transport times. Quite surprisingly, the longest descent analysed (15-17 d) led to negligibly low $\mathrm{H}_{2} \mathrm{O}$ in the DIAL measurements at UFS (Trickl et al., 2015, 16 July, 2013).

Intrusions reaching altitudes around $3 \mathrm{~km}$ were verified by looking at the Zugspitze ozone and RH data until 2010 and the UFS data afterwards. As pointed out in Sect. 2.1.3, the Zugspitze RH rarely dropped clearly below $10 \%$ due to an obvious bias.

\subsection{Typical findings}

As previously discussed (Trickl et al., 2010), stratospheric air intrusions passing over Garmisch-Partenkirchen arrive from almost all directions. Easterly directions mostly result from detours of the dry layers via eastern Europe or curl formation over central Europe potentially in cut-off lows.

Intrusion layers can be observed under many different conditions. We routinely observe pre-fontal and post-frontal intrusion layers, as well as intrusions slowly descending from the far west. The pre-frontal cases are frequently associated with stratospheric air masses descending from the Arctic to northern Africa or the Mediterranean basin followed by some return flow to central Europe. These layers normally rise as they are on a transition into a warm conveyor belt (e.g. Cooper et al., 2004). Post-frontal intrusions mostly reach low altitudes above Garmisch-Partenkirchen and occur after virtually all cold fronts, of course also in the "classical" case of beginning anti-cyclonic conditions (e.g. Stohl and Trickl, 1999; Trickl et al., 2003). They can, however, also occur between two frontal passages that are sometimes separated by no more than $1 \mathrm{~d}$. In these cases the inclined descending layer can be sandwiched between the low-lying clouds of the preceding front and the high-lying clouds of the incoming new front.

A few specific remarks:

1. Very intense intrusions have been rare. Although intrusions with 100-150 ppb of ozone in the middle and upper troposphere are not that rare, much higher values are really exceptional. Just three cases with peak ozone mixing ratios reaching or exceeding $200 \mathrm{ppb}$ have been found during the entire period described here (20072016). The most intense intrusion, also covering a wide vertical range, was observed on 1 October 2015 (Fig. 2). The peak ozone mixing ratio on that day was $235 \mathrm{ppb}$ and rapidly dropped to less than $100 \mathrm{ppb}$. For comparison we give average values of the in situ GAW measurements at UFS $(2670 \mathrm{~m})$. The ozone minimum at $12.2 \mathrm{~km}$ (07:52 CET) is close to the upper end of the operating range of the lidar for these extreme concentrations, but is clearly visible and ascribed to the tropopause. This is justified by the position of the Munich tropopause that descended from 13341 to $11903 \mathrm{~m}$ from midnight until noon.

The UFS ozone data exhibit a slight negative bias of 2 to $4 \mathrm{ppb}$ in the morning. This bias is outside typical differences between the lidar and UFS or Zugspitze summit and is ascribed to orographic lifting of the air masses that arrived from the east (see below), along the former glacier basin. 


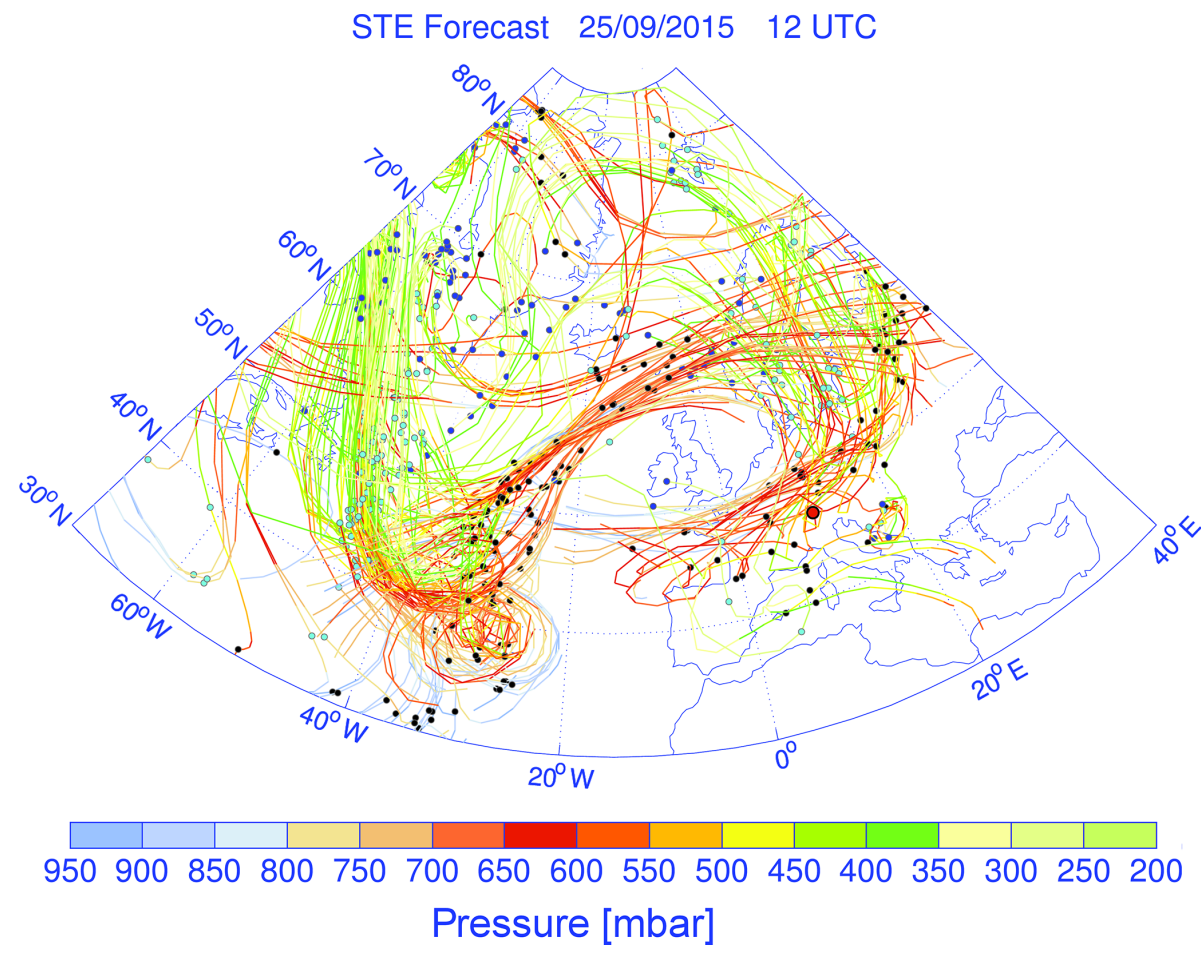

Figure 3. Recalculation of the LAGRANTO forward trajectories based on ERA-Interim wind data: the length of the trajectories is 5 d. Less than $1 \%$ of the trajectories are displayed for clearness. The pressure level is colour coded in mbar. The start time $t_{0}$ is 25 September 2017 , 12:00 UTC (13:00 CET), marked with dark blue dots. The times $t_{0}+2 \mathrm{~d}$ and $t_{0}+4 \mathrm{~d}$ are marked with bright blue and black dots, respectively. The red dot north of the Italian peninsula marks the position of Garmisch-Partenkirchen.

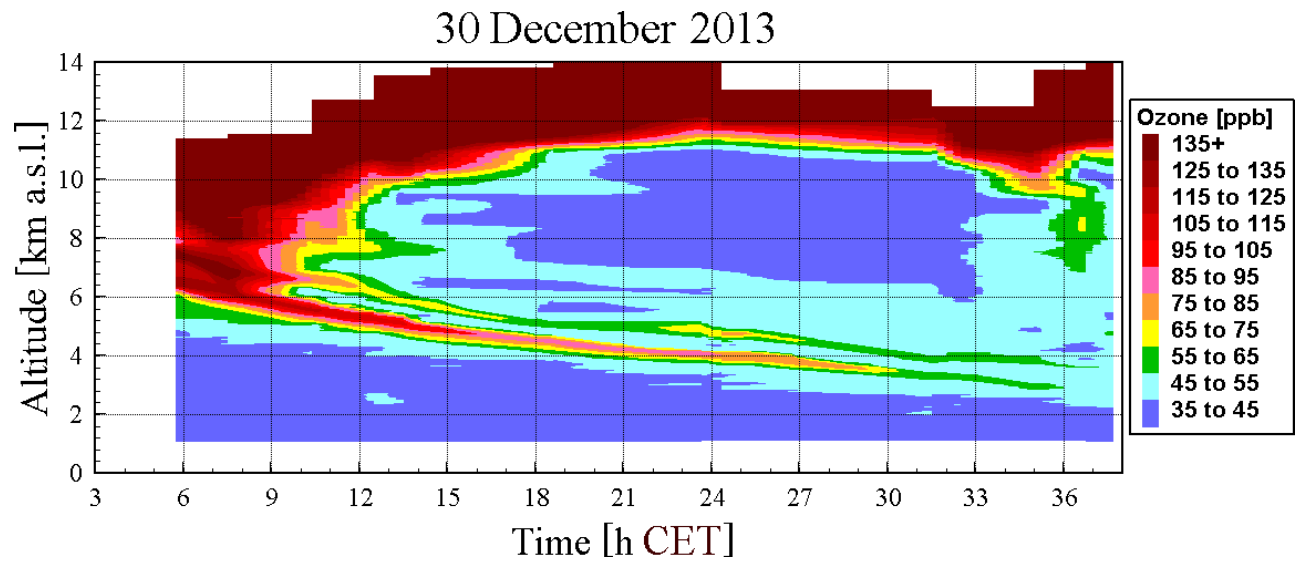

Figure 4. DIAL ozone soundings on 30-31 December 2013 showing two narrow layers descending parallel to below $4 \mathrm{~km}$ a.s.1.

The presence of an intrusion on 1 October 2015 had been predicted by the LAGRANTO operational forecasts. For this paper the trajectory calculations were repeated with ERA Interim re-analysis data and extended from 4 to $5 \mathrm{~d}$. In Fig. 3, we give one example for a start time of 12:00 UTC (13:00 CET) on 25 September. The trajectories clearly show a stratospheric intrusion passing over Garmisch-Partenkirchen. The plot is rather complex because several intrusions co-exist. This start time is slightly too early with respect to the lidar observations to avoid even higher complexity. However, the principal advection path of the observed intrusion remained for the later times and is explained in the following.

Figure 3 and the trajectory plots for later times show high-lying and low-lying trajectories over southern Germany and qualitatively confirm the observations in Fig. 2. The trajectories passing over Garmisch- 

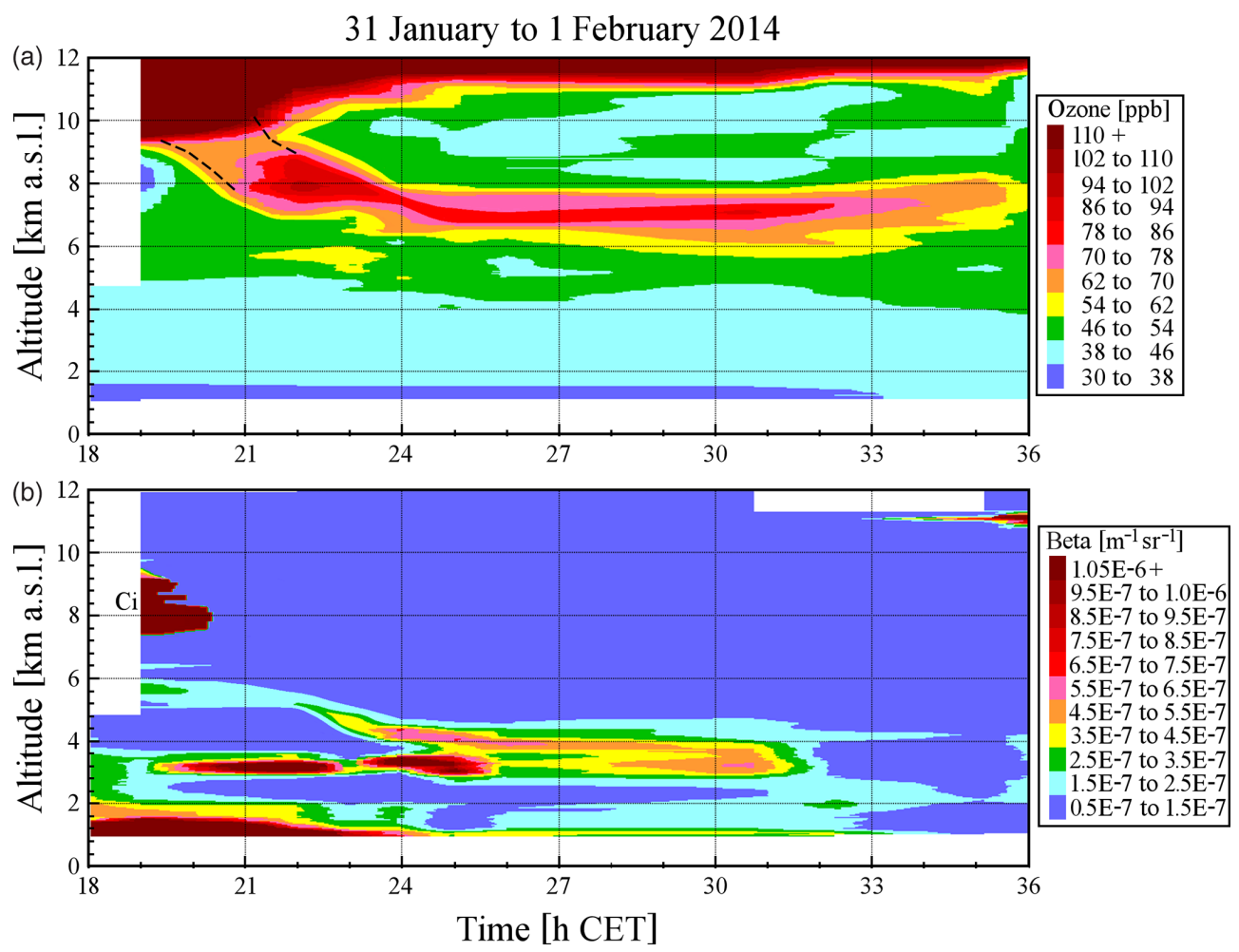

Figure 5. Time series of ozone (a) and the $313 \mathrm{~nm}$ aerosol backscatter coefficient (b) on 31 January and 1 February 2014: Both a stratospheric intrusion layer $(6.5-9 \mathrm{~km})$ and a weak to moderate Saharan dust event 2.5-6 km are seen. Due to a $3 \mathrm{~h}$ data gap between 19:00 and 22:00 CET the colour coding during this period is highly uncertain. The intrusion could also have formed a full tropopause fold as indicated by the dashed black lines.

Partenkirchen start over northern Greenland, pass over (or near) Svalbard and then turn southward towards eastern Europe. This is exactly confirmed by the HYSPLIT backward trajectories that allow one to select start times and altitudes above the lidar (not shown). The highest altitude $(>11 \mathrm{~km})$ is reached above northern Greenland.

Further exceptional mixing ratios were observed on 26 February 2015 (235 ppb), and, in a particularly spectacular case (Trickl et al., 2014), on 6 March 2008 (200 ppb).

2. Extremely thin layers can survive the long-range transport with almost negligible mixing. The width of intrusion layers can vary considerably from case to case. Layer widths clearly exceeding $2 \mathrm{~km}$, in particular that in Fig. 2, are not frequent, in agreement with the analysis of Colette and Ancellet (2005). Also very thin layers with widths of down to $0.2 \mathrm{~km}$ have been observed. Both IFU DIAL systems are capable of resolving these structures, and there is mostly very little mixing with tropospheric air (Trickl et al., 2014, 2015, 2016). A particularly spectacular case (26-27 December 2008) of a thin, very dry $(\mathrm{RH}=1 \%$, the obvious cut-off level of the sonde data) layer was discussed by Trickl et al. (2014) and verified by high-verticalresolution FLEXPART transport modelling. Here, we show as an example an even more exciting case from December 2013 of two parallel very thin high-ozone layers descending to Alpine summit levels (Fig. 4). Again, the minimum RH was $1 \%$.

3. Slow long-distance descent (Type 6) dominates the observations above about $4.5 \mathrm{~km}$. The slow descent of stratospheric layers from remote source regions such as western Canada, Alaska or even Siberia down to Alpine summit levels was identified by Trickl et al. (2010). These Type 6 intrusions were observed much more frequently above $4.5 \mathrm{~km}$ than at the Zugspitze summit (see Sect. 3.4). A particularly spectacular case on 16 July 2016 was analysed by Trickl et al. (2015): the trajectories indicated a descent from the stratosphere above Siberia over roughly 2 weeks without a resolvable rise in humidity. A source of STT can also be the subtropical jet stream over Asia, reaching mid and high latitudes over the Pacific Ocean (Trickl et al., 2011). This kind of pathway was also found for some of our more recent observations during the warm season.

4. Intrusion layers frequently arrive via northern Africa. Long fronts reaching as far as the Sahara are typically 
NOAA HYSPLIT MODEL

Backward trajectories ending at 23:00UTC 31 Jan 14

CDC1 meteorological data

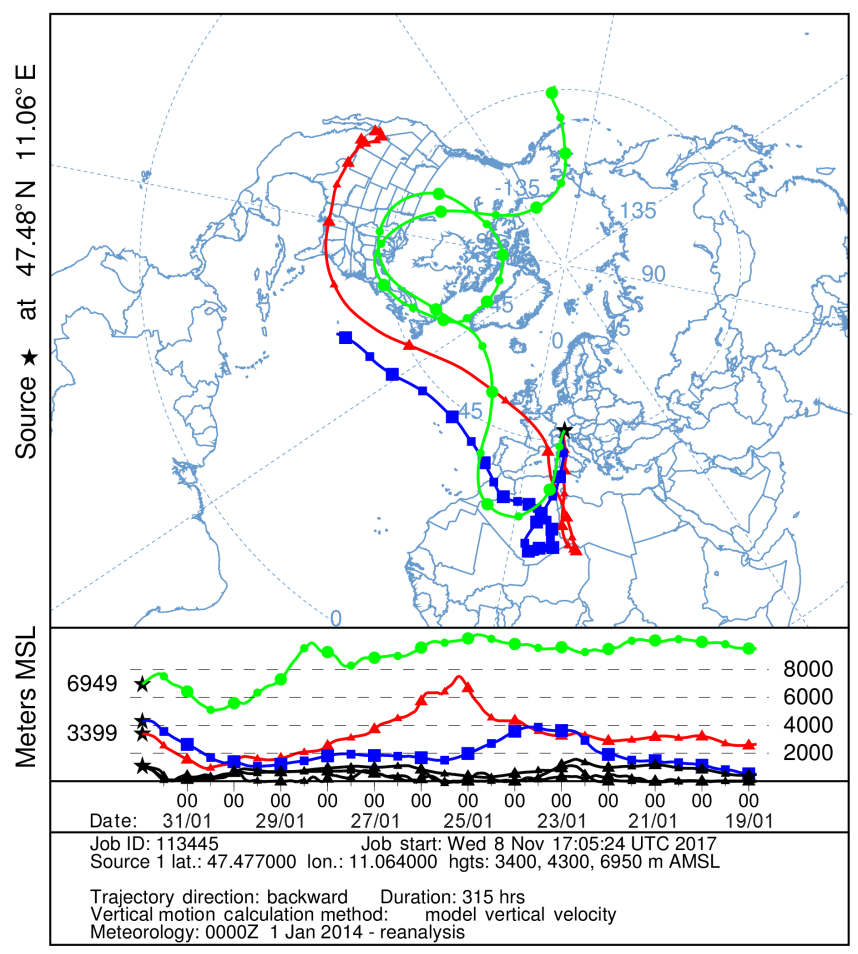

Figure 6. Selected HYSPLIT $315 \mathrm{~h}$ backward trajectories starting above Garmisch-Partenkirchen on 1 February 2014 at 00:00 CET within the two aerosol layers in Fig. 5 (lower panel) between 3 and $4.5 \mathrm{~km}$ as well as in the stratospheric intrusion between 6 and $9 \mathrm{~km}$ (upper panel in Fig. 5); the black curves at the bottom of the vertical cross section mark the ground levels for each trajectory.

associated with the advection of dust (Papayannis et al., 2008). Pre-frontal intrusion layers have been mostly located above the dust layer (exceptions exist). In Fig. 5 we show time series of the ozone aerosol profiles on 31 January and 1 February 2014, and Fig. 6 displays three HYSPLIT trajectories selected for the three relevant ozone and aerosol layers at midnight between the two days. The dust was lifted to roughly $5 \mathrm{~km}$, which is typical of these Föhn events at the northern rim of the Alps (e.g. Jäger et al., 1988). Above the dust layers a layer with elevated ozone passed over GarmischPartenkirchen. The minimum Munich RH on 1 February at 01:00 CET was 2\%, indicating a moderate travel time (the UFS DIAL was not operated). The intrusion trajectory in Fig. 6 shows rather rapid transport from about $10 \mathrm{~km}$ above Cape Farvel (Greenland) to northern Africa. Obviously, this high speed makes it possible to pass eastward over the southern part of the front and enter the air stream rising to the Alps. The LAGRANTO STT forecast confirms at least subsidence from Labrador to northern Africa.
Another dust case is shown in Figs. 7 and 8 for 18 June 2013, this time combined with long-range descent from the northern United States (US) (and presumably beyond) and a single-loop curl at low latitudes, with a corresponding trajectory analysis in Fig. 8. Here, the intrusion air mass crossed the cold front over western Spain or Portugal. At 13:00 CET on 18 June this front extended north-south from Bristol (UK) to northern Africa. Obviously, the upper end of the clouds was rather low in this area, similar to the May 1996 case (Trickl et al., 2003). The RH determined from a comparison of the results of the water-vapour DIAL (Fig. 7b) and the Munich radiosonde was $8 \%$ to $12 \%$. These rather high values are ascribed to the very long descent during at least $13 \mathrm{~d}$.

Intrusions co-existing with Saharan dust were observed on a total of $67 \mathrm{~d}$. The number of dust days in our record is limited because frequently dust arrives below clouds, which impedes lidar measurements.

5. Summer-time ozone in the middle and upper troposphere has been frequently high. Elevated ozone was a feature observed many times above about $4.5 \mathrm{~km}$ during the warm season. Two examples from May and August 2015 are shown in Fig. 9. In both cases (and most others) dry layers exist within the high-ozone range and the corresponding HYSPLIT trajectories stay at high altitudes. For the altitudes in these examples analysed with trajectories we did not find any contact with potentially polluted planetary boundary layer (PBL) within the maximum of $315 \mathrm{~h}$ provided by the model. However, the calculation for a cirrus layer around $7.5 \mathrm{~km}$ on 10 August ended around $5 \mathrm{~km}$ over the Pacific, giving some hint on the origin of the moisture required for the cloud formation.

6. Volcanic and fire aerosol are transported downward from the lowermost stratosphere. During the periods of major volcanic activity impacting the lower stratosphere, aerosol was frequently detected in intrusion layers (see also Browell et al., 1987). More specifically, particles in intrusion layers were registered after the eruptions of Okmok and Kasatochi (July and August 2008, respectively; see Trickl et al., 2016), Redoubt (March 2009), Sarychev (June 2009) and Nabro (June 2011) (more details: Trickl et al., 2013). Typical $313 \mathrm{~nm}$ aerosol backscatter coefficients were $5 \times$ $10^{-7} \mathrm{~m}^{-1} \mathrm{sr}^{-1}$ and less. The highest value was $2.35 \times$ $10^{-6} \mathrm{~m}^{-1} \mathrm{sr}^{-1}$, observed on 7 September 2009 after the violent eruption of Sarychev. Stratospheric intrusions have been identified as a highly important mechanism for the rapid depletion of stratospheric aerosol in the mid-latitudes within 1 year or less (Deshler, 2008; Trickl et al., 2013). This includes strong fires (pyro-Cbs) that normally just reach the lowermost stratosphere (e.g. 
Fromm et al., 2008, 2010), the latest presumable smoke case being 2 October 2017 for the strong fires in British Columbia that were observed up above our site to an exceptional $20 \mathrm{~km}$ (not shown). Tropospheric smoke has also been found in intrusions (Trickl et al., 2015).

7. Dry air layers can also arrive from the lower-latitude Atlantic. Quite a few of the dry layers with elevated ozone have been traced back to the south-west of the Azores. Here, the trajectories frequently form curls or spirals exiting backward towards the north-west (e.g. Fig. 8). In several cases extension trajectories were calculated and confirm descent from high altitude at high latitudes. Only these verified cases were accepted as "stratospheric", given the low humidity.

8. Intrusions rarely penetrate into the $P B L$. During the past decade there has been enhanced interest in the role of STT in air quality (e.g. Lefohn et al., 2011; Langford et al., 2012; Lin et al., 2012, 2015). We have routinely observed ozone peaks below $2000 \mathrm{~m}$, but have not analysed penetration of intrusions into the PBL in detail because of the absence of water-vapour measurements below $3000 \mathrm{~m}$ that could identify intrusions even without pronounced ozone structure. However, we have observed intrusions sliding along the top of the PBL over several days without a clear indication of penetration into it. This suggests that descent towards the ground is likely to occur mostly during night-time at the end of the primary subsidence. This could explain why Reiter et al. (1990), based on years of ozone soundings with the Eibsee-Zugspitze cable car ( $1.0 \mathrm{~km}$ to $2.95 \mathrm{~km}$ a.s.1.), did not observe any case of subsidence to below 1.4$1.6 \mathrm{~km}$ a.s.l.: the cable car runs only during day-time. In fact, Eisele et al. (1999) reported a case of sufficiently deep early-morning descent of a STT layer that it could be caught by the forming PBL. Similar conclusions are reported by Ott et al. (2016).

\subsection{STT and long-range transport of boundary-layer ozone}

The typical ozone rise to sometimes even more than $100 \mathrm{ppb}$ in the middle and upper troposphere during the warm season mentioned in Item 5 of Sect. 3.2 is remarkable. Since such behaviour is mostly absent during the darker period of the year, this could suggest that a higher ozone background due to strong photochemical activity is imported from remote regions such as North America or East Asia. An analysis carried out in 2005 based on FLEXTRA (e.g. Stohl et al., 1998) trajectories limited to just $8 \mathrm{~d}$ backward in time yielded North American influence over Garmisch-Partenkirchen during already $28 \%$ of the time for the period April 2003September 2004 (ATMOFAST, 2005).

Since we did not analyse vertical ranges with constant moderate ozone for the period since 2007, this could suggest that the air quality in the United States (US) has improved. Nevertheless, we did identify several cases of intercontinental transport of pronounced amounts of ozone. One of these cases is described below. In general, a clear distinction of long-range advection from the stratosphere or a polluted PBL is a complex task beyond the scope of this paper. It requires more suitable analysis tools such as the FLEXPART model as applied by us in detail in previous studies (e.g. Trickl et al., 2003, 2010, 2011). There, we extended FLEXPART-based analyses to up to 20 days and found merging air streams from the stratosphere and remote boundary layers (Trickl et al., 2011).

It is very difficult to estimate the stratospheric contribution in the summertime middle and upper troposphere. The sonde data show very low humidity mostly in rather confined layers and rarely in the entire range with elevated ozone. This can indicate mixing in merging air streams, but could also be attributed to differences in vertical distribution with respect to the rather remote radiosonde stations. In the case of mixing, an assessment of the stratospheric component would have to rely on model-based estimates, which can be rather crude (e.g. Trickl et al., 2014).

As one example of a significant North American ozone plume we describe here the case of 28 May 2015. On that day a major part of the summertime ozone step could be related to a high-ozone episode in the eastern US. Again, a part of the step (the lowest section) is related to STT. The ozone profiles from that day are displayed in Fig. 10. At almost all tropospheric altitudes there were (in part remarkable) changes in ozone that could be explained by the RH and trajectory analyses. In the morning two intrusion layers from source regions around Alaska are discernible at about 4.7 and $3.1 \mathrm{~km}$ ( $\mathrm{RH}=6 \%$ and $4 \%$, respectively). The trajectories seem to continue rising for backward times beyond $-315 \mathrm{~h}$ to altitudes higher than $7 \mathrm{~km}$. These intrusions diminish later on.

In the afternoon an ozone step to roughly $80 \mathrm{ppb}$ formed above $6.7 \mathrm{~km}$ (light blue, red and grey curves in Fig. 10). The air mass was rather humid (Munich sonde RH 50\%$76 \%$ at 13:00 CET; some backscatter profiles showed signal from cirrus clouds), with the exception of the lowest peak for which the Munich radiosonde yielded $\mathrm{RH}=4 \%$ (there at $7.6 \mathrm{~km}$ ). Figure 11 shows three $315 \mathrm{~h}$ HYSPLIT backward trajectories selected for relevant altitudes above our site $(7400,8200,8500 \mathrm{~m})$ from a larger number of trajectories calculated. The ozone rise near $7 \mathrm{~km}$ corresponds to longrange descent from northern Alaska, in agreement with the low RH.

The higher trajectories bend southward over the Great Lakes and follow the Mississippi back to the Caribbean Sea. On 24 May an altitude of $1.5 \mathrm{~km}$ is reached, i.e. above Louisiana. The strong air-mass rise from the Gulf of Mexico to Canada suggests the presence of a warm conveyor belt. Indeed, we verified the presence of a rather wide warm conveyor belt with tools described by Madonna et al. (2014) and Sprenger et al. (2017). To the east a wide zone with 

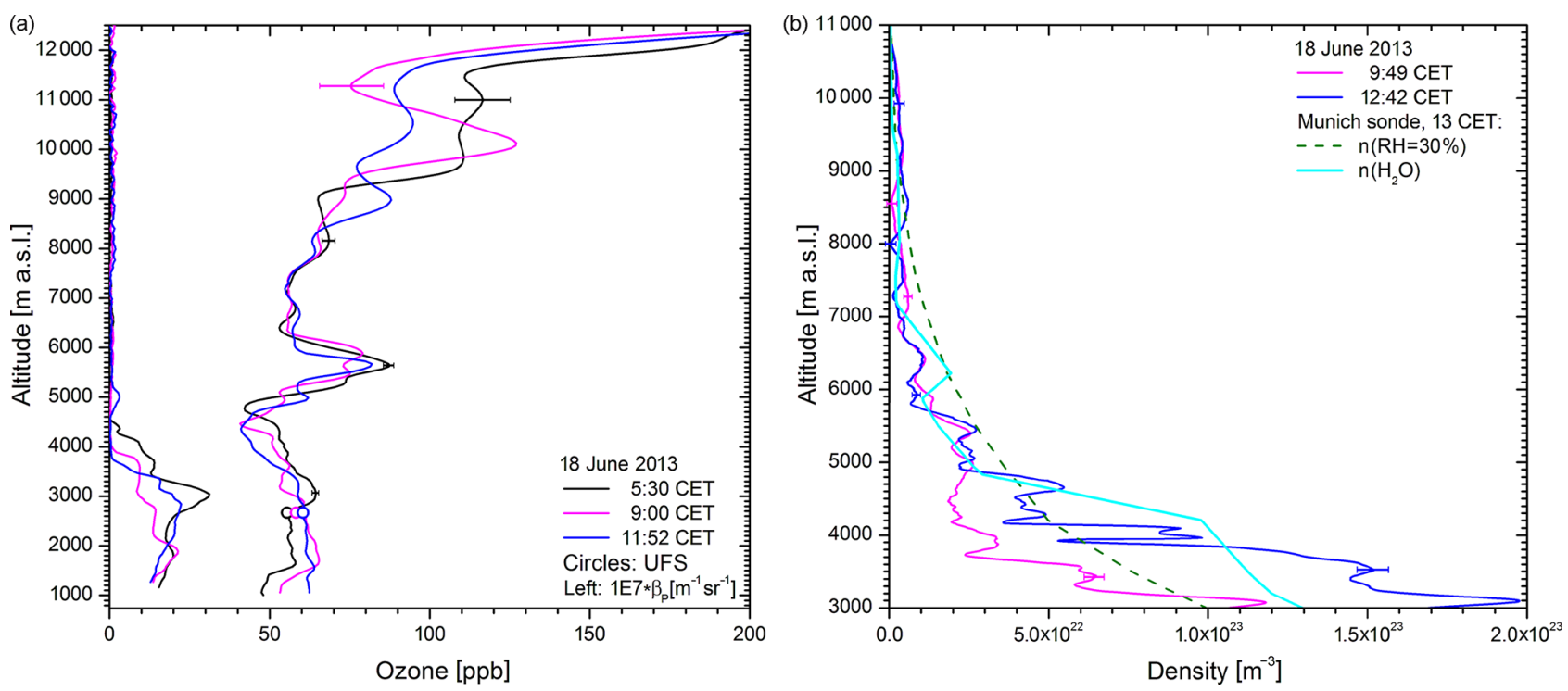

Figure 7. Profiles of ozone, the aerosol backscatter coefficient (a) and the water-vapour number density $n$ (b) from DIAL measurements at IFU and UFS on 18 June 2013 during a Saharan dust event; the $250 \mathrm{~m}$ upward displacement of the humidity minimum with respect to the ozone maximum is ascribed to orographic effects. For comparison, the densities for $\mathrm{RH}=30 \%$ and the measured $\mathrm{RH}$ by the Munich radiosonde are shown. The stratospheric intrusion peak at around $5.7 \mathrm{~km}$ corresponds to $8 \%-12 \% \mathrm{RH}$ because of long-range descent (Fig. 8). The times specified for the UFS DIAL are the end times of the respective measurement (lasting about 16 min). The in situ data of UFS $(2670 \mathrm{~m})$ are marked with circles coded in the same colours as the lidar measurements next to the same time and confirm the values from the lidar measurements within 1-2 ppb.

peak ozone exceeding $80 \mathrm{ppb}$ is revealed in Fig. 12, indicating long-lasting high pressure. Ozone maps from the US Environmental Protection Agency (https://www.epa.gov/ outdoor-air-quality-data/, last access: 2 January 2020) confirm a moderate ozone rise, particularly over Illinois and Kentucky exactly on 23 May. The trajectories propagate along the western side of the high-ozone zone in Fig. 12 and indicate some overlap with this region. This result is rather satisfactory and confirms our excellent experience with the HYSPLIT run with the re-analysis option. In fact, we also tested the GDAS option that offers better spatial resolution. As in earlier comparisons (e.g. Trickl et al., 2016), we found strong deviations from Fig. 11, with almost all trajectories leading backward to Alaska at high altitudes, approximately parallel to the red $7400 \mathrm{~m}$ trajectory in Fig. 11. This result is in considerable disagreement with the RH data that show a narrow dry layer just above $7 \mathrm{~km}$ and elevated humidity at higher altitudes that is in excellent agreement with the import from the Caribbean Sea suggested in Fig. 11 and the cirrus signal in the lidar backscatter data.

\subsection{Statistical analysis of STT}

The ozone profiles alone do not allow us to quantify freetropospheric ozone budget due to STT. The boundaries of the intrusion layers cannot always be clearly distinguished. Water-vapour profiles show a clearer contrast and can be used for identifying the range of the STT layers. The soundings with the nearby $\mathrm{H}_{2} \mathrm{O}$ DIAL are adequate. However, they were not always made on the same day and sometimes not even within the same range of hours, which reduced the number of intrusion cases on which the stratospheric ozone content could be determined. Radiosonde data can only be used as a qualitative tool to verify the presence of an intrusion layer in the region due to the long distance to the stations.

As a consequence, we decided for the current study to perform a statistical analysis of the fraction of the measurement days per month with one more identified intrusion layer (Sect. 3.1), similar to the approach by Beekmann et al. (1997; see Sect. 4). The seasonal cycle from our analysis is shown in Fig. 13, based on all (585) measurement days for each month between 2007 and 2016. The month-to-month variation of the fractions is rather low. We derived a standard deviation of the fraction from months with at least 8 measurement days. The resulting overall standard deviation was 0.12 , which looks unrealistically high considering the smoothness of the data in Fig. 13 and is ascribed to the reduction of the data set in this procedure.

In order to demonstrate that there is no bias due to the choice of the measurement days, we also show the results for Monday and Thursday, i.e. the EARLINET "climatology days" (a total of 286). Due to the reduction in days, the variability is higher. Nevertheless, the principal course of the seasonal cycle is retained and no significant bias is seen. Just for the period December to February the deviations are larger due to a smaller number of climatology days covered. 


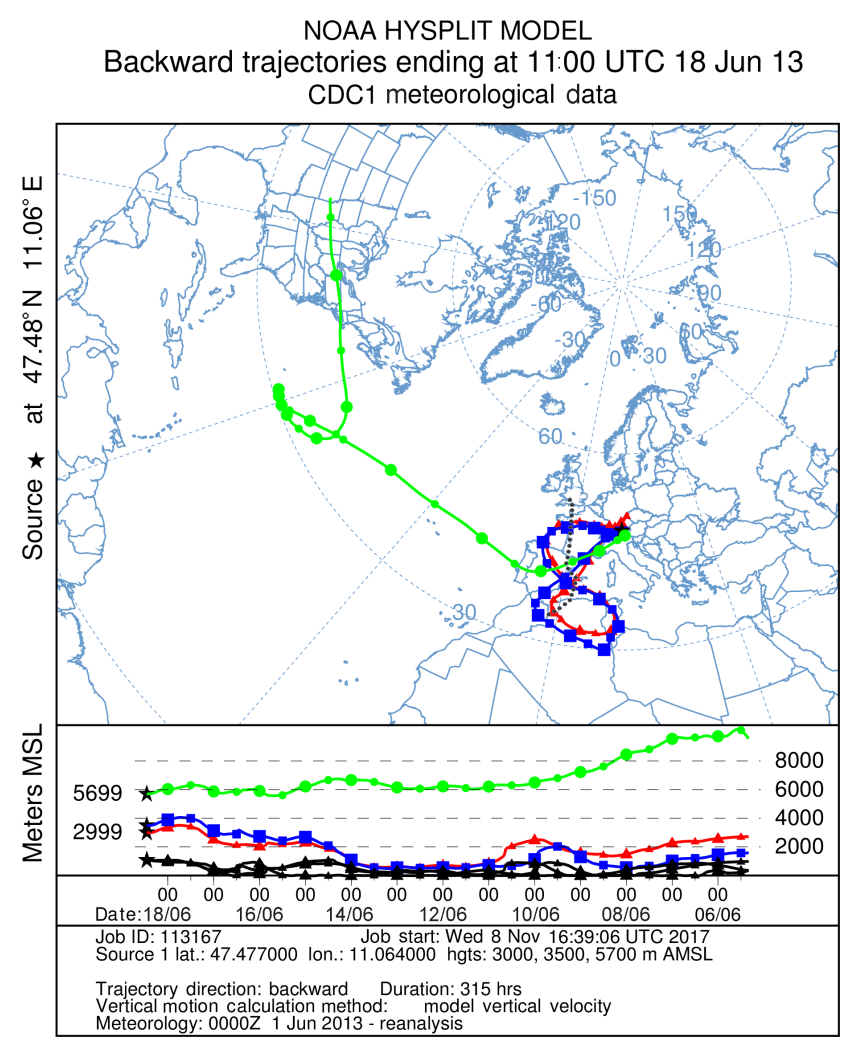

Figure 8. Selected HYSPLIT $315 \mathrm{~h}$ backward trajectories starting above Garmisch-Partenkirchen on 18 June 2013 at 11:00 UTC (12:00 CET) within the Saharan dust layer as well as in stratospheric intrusion at $5.7 \mathrm{~km}$ (see Fig. 5); the black curves at the bottom of the vertical cross section mark the ground levels for each trajectory. The dotted black line indicates the arriving cold front on 18 June 2013, 13:00 CET.

Similarly to Beekmann et al. (1997) we find just a rather weak seasonal cycle of the fraction of intrusion days. However, our average fraction of $84.1 \%$ is much higher than that in their study (4.8\% for Uccle, Belgium). We discuss this fact in Sect. 4. A slight seasonal maximum is visible in Fig. 13 around August, resembling the findings by Beekmann et al. (1997) for the observational criteria used in their study.

Considering the pronounced summer minima of deep STT obtained for the Alpine summit stations Jungfraujoch (3580 m), Zugspitze (2962 m), and Sonnblick (3106) and station Monte Cimone $(2165 \mathrm{~m})$ in the northern Italian Apennines (Stohl et al., 2000; Trickl et al., 2010), there must be a pronounced free-tropospheric summer maximum of the STT fraction to explain the overall seasonal cycle with a slight maximum in August.

As mentioned, the overall seasonal cycle in Fig. 13 is dominated by Type- 6 intrusions (Trickl et al., 2010), i.e. intrusions that originate in source regions far to the west, including East Siberia. Most of these intrusions descend just to 4.5 to $5 \mathrm{~km}$ and are, thus, frequently missed at the Alpine sta- tions. From the 3 years best covered by measurements, we determined a fraction of STT days with at least one Type- 6 intrusion of $48 \% \pm 13 \%$. Trickl et al. (2010) found a fraction of just $12 \%$ in their analysis of the Zugspitze data.

For comparison with the Zugspitze results, we provide in Fig. 13 the fractions of days on which $3.0 \mathrm{~km}$ was reached. These fractions agree rather with those from the analysis of the Zugspitze in situ data for 2001-2005 in Trickl et al. (2010), shown in Fig. 13 as "TT2010". The distributions agree rather well. However, the lidar-based fractions are rather noisy due to the worse data coverage in comparison with the in situ data. This may have influenced in particular the deviations from the Zugspitze analysis for January and March. However, since 2008 rather cold winters have prevailed and perhaps could have led to a weaker influence of the North Atlantic storm track and less frequent deep intrusions in January. The March maximum in the Zugspitze fraction was caused by an elevated count of 6 and 4 deepintrusion days in March 2014 and 2015, respectively. These were the only years with a reasonable number of measurement days in March, which could suggest the occurrence of a positive outlier. On the other hand, the FLEXPART simulation in Fig. 1 of Trickl et al. (2010), made for 1995-1999, shows a pronounced maximum in March.

As pointed out by Trickl et al. (2014), deep intrusions subsiding to $5.5 \mathrm{~km}$ and less were observed by the water-vapour DIAL on a total of $80 \mathrm{~d}(2004,2007-2013)$. This means a fraction of $32 \%$ of the measurement days, i.e. already more than the roughly $20 \%$ obtained for the Zugspitze summit, which confirms the increase in intrusion numbers with growing altitude.

The peak ozone mixing ratio in intrusion layers can vary considerably from case to case. High ozone values beyond $100 \mathrm{ppb}$ are mostly limited to altitudes above $5 \mathrm{~km}$. However, very recently (on 3 November 2017) we found as much as $95 \mathrm{ppb}$ of ozone in a layer centred at $3.0 \mathrm{~km}$ and featuring a full width at half maximum of just $0.2 \mathrm{~km}$. In order to see if there is a systematic seasonal variation we determined the seasonal cycle of the "weak" and "strong" intrusions in the free troposphere (Fig. 14). The intrusions for which the peak ozone values exceeded the neighbouring ozone "background" by less than $15 \mathrm{ppb}$ exhibit a summer minimum, whereas those with an exceedance of more than $40 \mathrm{ppb}$ a summer maximum, with some contribution also from January to April. Trickl et al. $(2014,2016)$ hypothesized that the peak ozone concentration is related to how far the intrusion layer extends into the stratosphere when the descent starts. In this view the initial layer thickness would be most pronounced in summer.

Lidar observations are restricted to fair-weather conditions. Thus, the fractions derived in this study are likely to exhibit some fair-weather bias. To estimate the ozone import from the stratosphere we, therefore, selected the year 2014, when $70 \%$ of the EARLINET climatology days were covered by measurements. 2014 was also the only year with a 

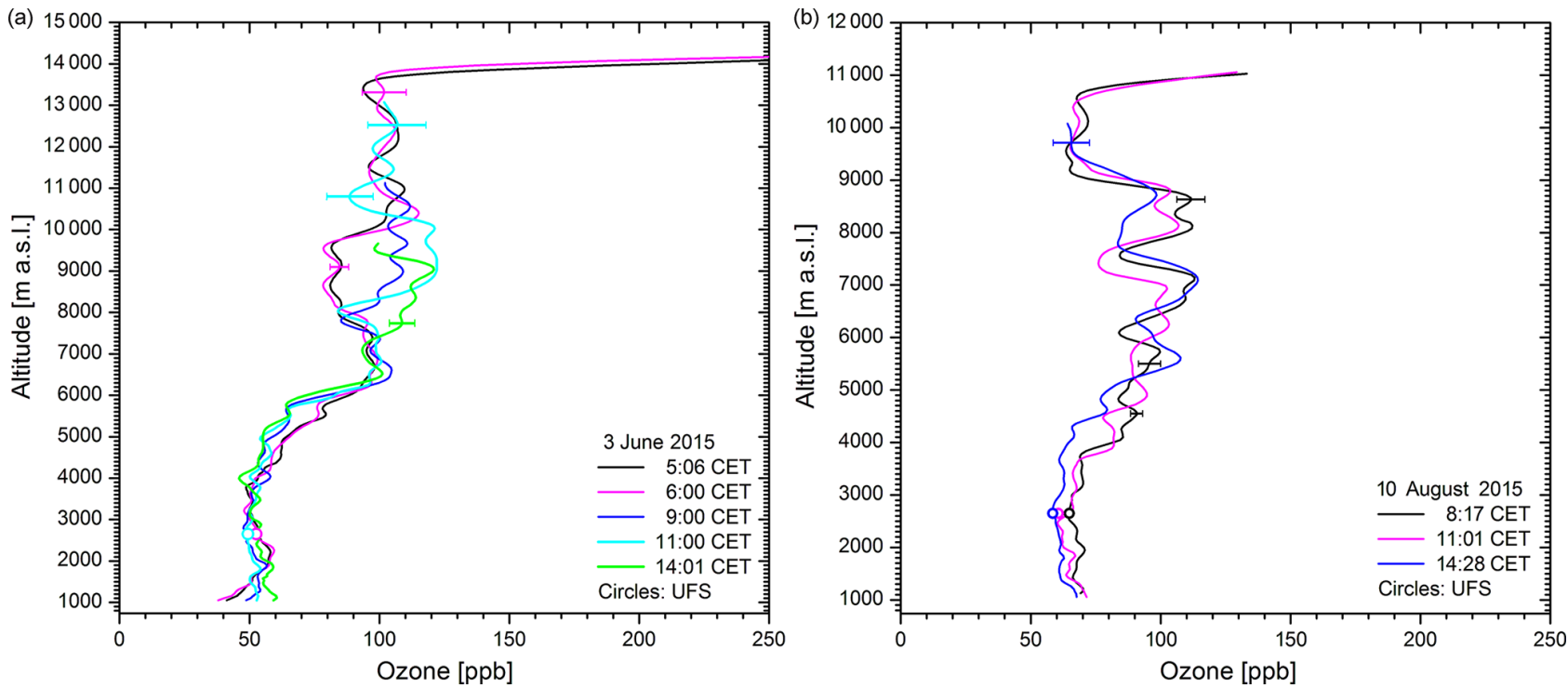

Figure 9. Ozone profiles from 3 June 2015 (a) and 10 August 2015 (b) showing very high ozone above 5 and $3.8 \mathrm{~km}$, respectively; the high values are mostly explained by STT. The in situ data ( $1 \mathrm{~h}$ averages) of UFS $(2670 \mathrm{~m})$ are marked with circles coded in the same colours as the lidar measurements next to the same time and confirm the values from the lidar measurements within 1 to 2 ppb. Munich tropopause: 13782 m (3 June, 00:00 UTC), 13764 m (3 June, 12:00 UTC), 12471 m (10 August, 00:00 UTC) and 11 029 m (10 August, 12:00 UTC).

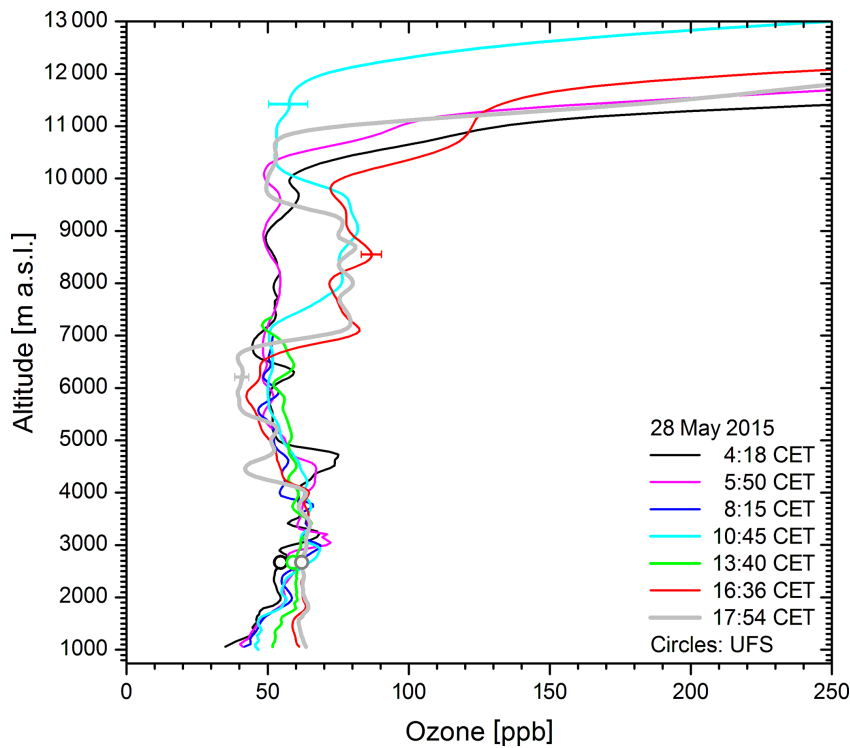

Figure 10. Profiles of ozone from DIAL measurements at IFU (Garmisch-Partenkirchen) on 28 May 2015; the pronounced diurnal cycle of the vertical distribution is ascribed to a quick change in source regions at different altitudes. Between 7.5 and $9.5 \mathrm{~km}$ about $80 \mathrm{ppb}$ from a high-ozone area in the US east of the Mississippi was observed. Intrusion layers are temporarily seen at about 3.1, 4.7 and $7.1 \mathrm{~km}$. The in situ data of UFS $(2670 \mathrm{~m})$ are marked with circles coded in the same colours as the lidar measurements next to the same time. The temporary upward shift of the tropopause (bright blue curve) was caused by a humid layer containing a cirrus cloud. high number measurements made in all months. The same high fraction of intrusion days (more than $80 \%$ ) was found as for the entire period. The missing $30 \%$ of climatology days were almost exclusively due to measurements prevented by bad weather. If one assumes that no intrusion was present on bad-weather days (which is not true according to the modelbased predictions), the overall fraction sinks from $84.1 \%$ to $59 \%$ which is, still, remarkably high. We derived for 2014 a very crude estimate of the average fraction of directly detectable stratospheric ozone in the free troposphere by considering its peak structure. This potentially conservative average fraction of $18 \%$ (varying from roughly $12 \%$ in winter to roughly $26 \%$ in summer), was obtained from determining for all days the ozone mixing ratio crudely integrated over all identified co-existing intrusion layers in comparison to the integrated ozone outside these layers up to the thermal tropopause on a given day. The width of a layer could frequently just be guessed.

This analysis cannot assess the role of stratospheric ozone fully mixed into the troposphere since this "indirect" contribution does not exhibit discernible ozone peaks and deep humidity minima. This indirect contribution cannot be estimated without model assistance. For the Zugspitze summit an estimate of the indirect component was made based on the ${ }^{7} \mathrm{Be}$ measurements (Fig. 1) that lead to an overall annual stratospheric ozone fraction of the order of $40 \%$ for the first years after 2000 . 
NOAA HYSPLIT MODEL

Backward trajectories ending at 17:00 UTC 28 May 15

CDC1 meteorological data

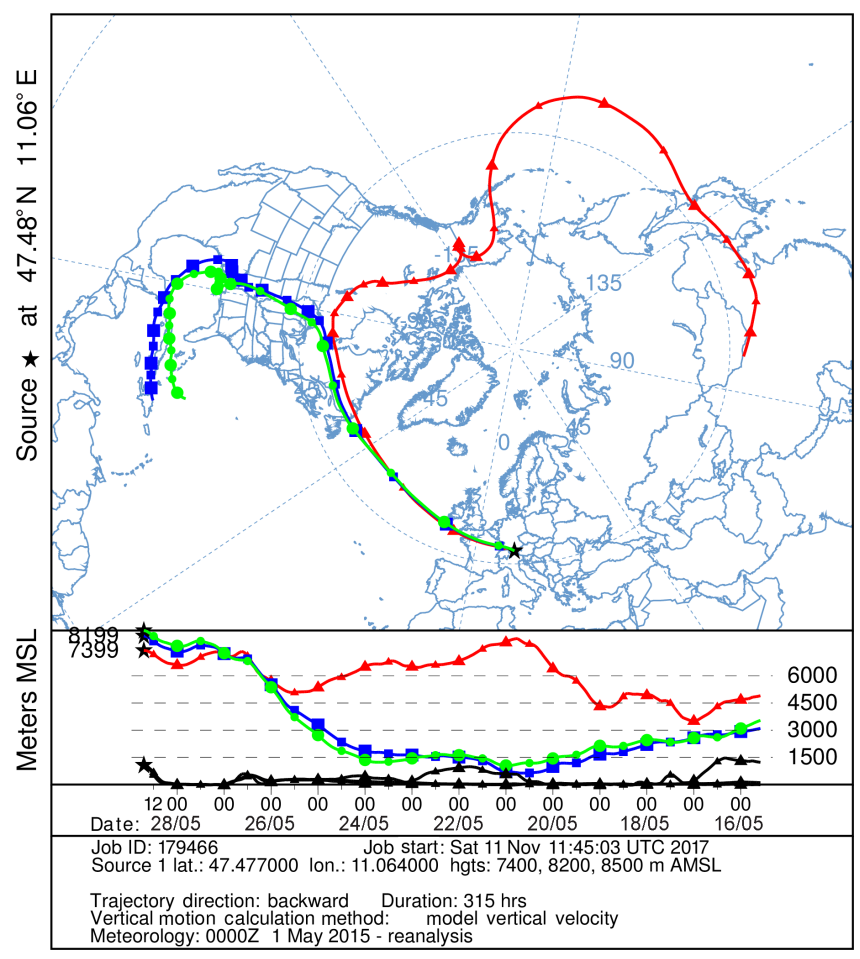

Figure 11. Selected HYSPLIT $315 \mathrm{~h}$ backward trajectories starting above Garmisch-Partenkirchen on 28 May 2013 at 17:00 UTC (18:00 CET) for three relevant altitudes in the high-ozone ozone range of Fig. 12; the black curves at the bottom of the vertical cross section mark the ground levels for each trajectory. The mountains on 22 May (Alaska) and 16 May (China) belong to the red trajectory.

\section{Discussion and conclusions}

The lidar measurements of tropospheric ozone at IMK-IFU have reached a performance that makes possible to resolve ozone structures with amplitudes of 5 to $10 \mathrm{ppb}$ up to the middle troposphere. This is particularly important during the cold season when a considerable number of intrusions with weak excess ozone occur (Fig. 14). Also in the upper troposphere because of the use of the $292-313 \mathrm{~nm}$ wavelength pair, considerable improvements have been achieved and structures with amplitudes of 10 to $15 \mathrm{ppb}$ can be resolved. This is important although intrusion peaks are usually more pronounced in this altitude range. Together with the humidity and trajectory analysis, it has allowed us to identify a high number of the stratospheric layers in the free troposphere.

The very large fraction of stratospheric intrusion days in our lidar measurements is an enormous surprise. The observed average percentage of $84.1 \%$ of all measurement days in the free troposphere since 2007 strongly exceeds the average fraction of about $17 \%$ observed at the neigh- bouring Zugspitze summit (2962 m) between 2001 and 2005 (Trickl et al., 2010). It strongly exceeds the $27 \%$ of temporal coverage of the measurements by tropopause folds determined from lidar measurements at the Table Mountain Facility in southern California between 2000 and 2015 (GranadosMuñoz and Leblanc, 2016), located at much lower latitude $\left(34^{\circ} \mathrm{N}\right)$. However, the Table Mountain seasonal cycle of the stratospheric fractions peaks at about $70 \%$ in winter and, during that period, almost matches our fraction. From July to September it minimizes at 1 to $2 \%$, in qualitative agreement with the jet-stream minimum over the western United States during that period (Koch et al., 2006).

STT analyses have also been derived from ozonesonde data (e.g. Beekmann et al., 1997; Colette and Ancellet, 2005; Kuang et al., 2017; Tarasick et al., 2019b). Routine operations are typically limited to just a single launch on 1 to $3 \mathrm{~d}$ per week. However, sondes offer the advantage of simultaneous measurements of ozone and RH as well as the absence of a fair-weather bias. The results obtained from the sondes have been rather controversial, which seems to be the consequence of the individual data-filtering approach. Recent sonde studies confirm a rather high percentage of STT: at the same latitude as Table Mountain, but in the south-eastern United States, ozonesonde measurements at Huntsville (Alabama, USA, $35^{\circ} \mathrm{N}$ ) were analysed between May and September 2013 (Kuang et al., 2017). There, the summer minimum was $23 \%$ (August), and $50 \%-60 \%$ was reached in May-June. A presumable winter maximum could, again, lead to even higher fractions. Tarasick et al. (2019b), in a series of sonde campaigns in Canada between 2005 and 2007, observed STT events every 2 to $3 \mathrm{~d}$ in spring and summer and every 4 to $5 \mathrm{~d}$ in autumn and winter. As in our observations, the stratospheric influence maximized in the middle and upper troposphere with an average of $34 \%$ (22 ppb) of directly identified stratospheric ozone. Colette and Ancellet (2005) made a thorough study for European stations back to 1970 based on about 27000 profiles. They concentrated on the statistics of individual intrusion layers and found a pronounced summer maximum of the ozone content of the layers.

By contrast, Beekmann et al. (1997) derived a much lower tropopause-fold fraction per year of just $5 \%$ from European sonde data for different periods around 1990. However, apart from this low fraction their work confirms the missing summer minimum for the free troposphere as a whole above our site.

This low fold fraction obtained by Beekmann et al. (1997) is puzzling. However, the data selection criteria in the 1997 assessment were much stricter than in the present study and in that by Granados-Muñoz and Leblanc (2016). The selection of cases by the observational groups in the 1997 effort was based on an ozone increase in a distinct layer by at least $25 \%$, a potential-temperature gradient of more than $11.5 \mathrm{~K} / 100 \mathrm{mbar}, \mathrm{RH}<25 \%$ and a wind speed of more than $20 \mathrm{~m} \mathrm{~s}^{-1}$. In addition, the vicinity of an upper tropospheric 


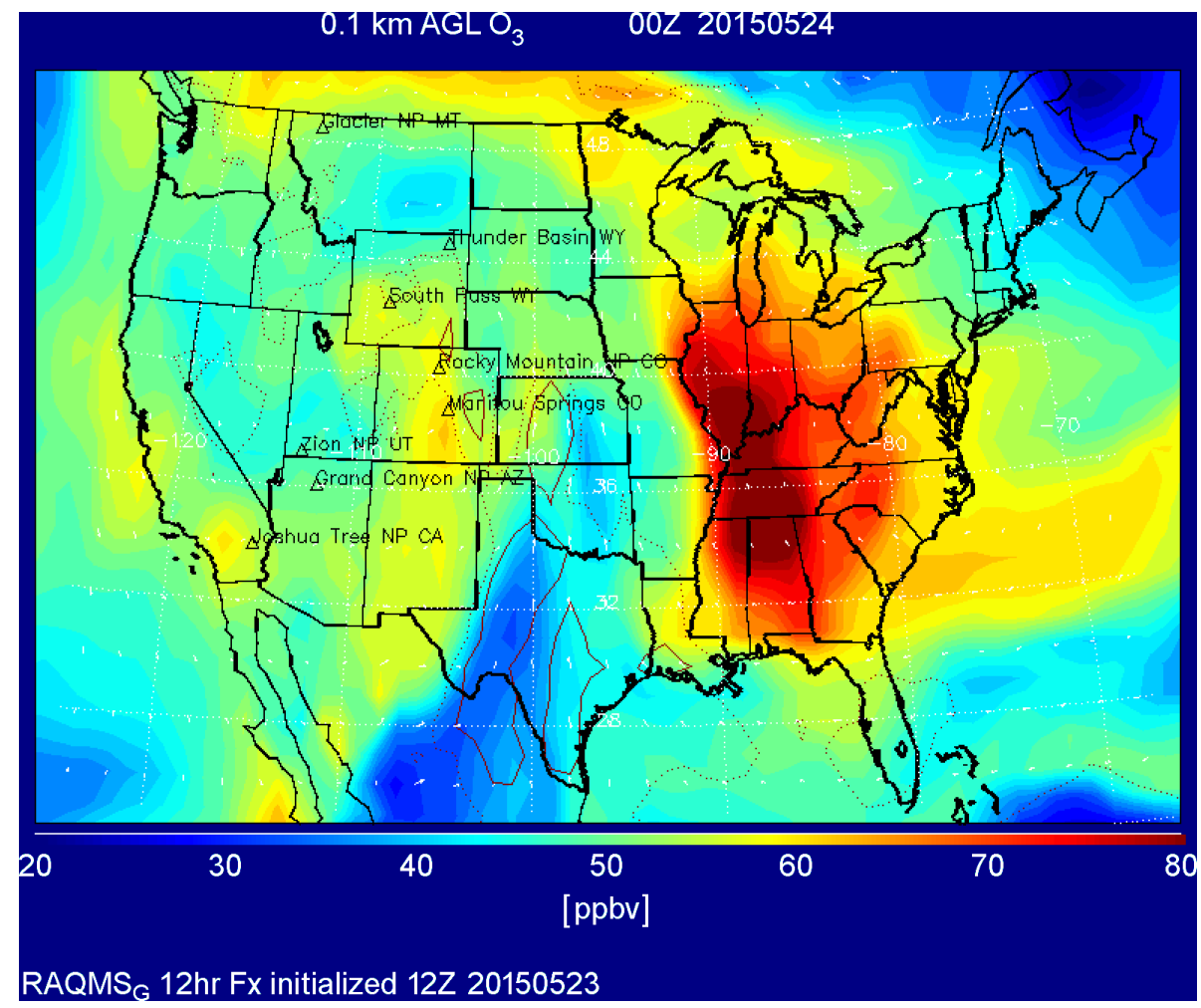

Figure 12. Ozone over the US on 24 May 2015 showing mixing ratios of more than $80 \mathrm{ppb}$ east of the Mississippi (RAQMS (Real-time Air Quality Modeling System) calculation kindly provided by Bradley Pierce (NOAA)).

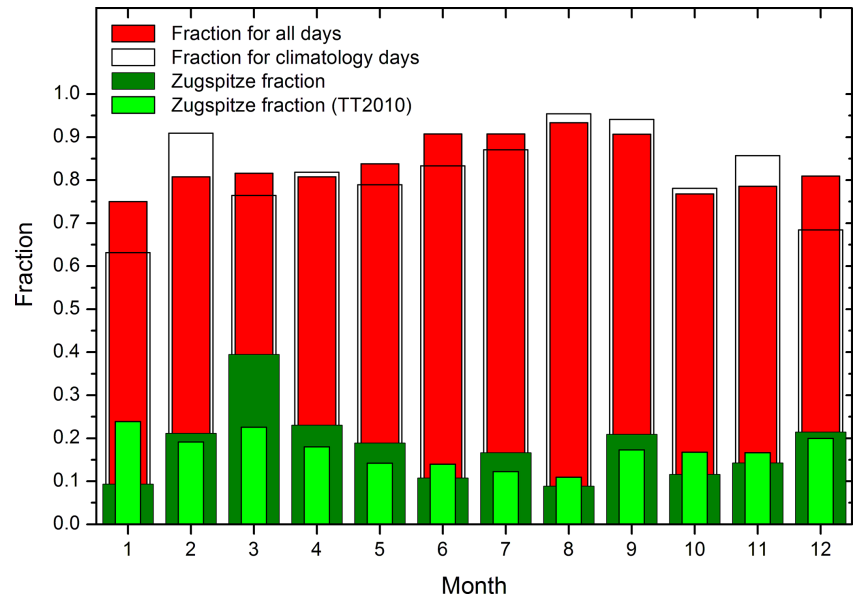

Figure 13. Fraction of intrusion days in the ozone lidar data averaged for each month between 2007 and 2016 (see text); we give the fraction for all measurement days (red bars) and for the "climatology days" Monday and Thursday (transparent bars). For comparison, the same analysis is shown for those intrusion days that show stratospheric influence at $2962 \mathrm{~m}$ (Zugspitze, dark green), together with the maximum fractions calculated from the Zugspitze in situ data underlying Fig. 12 in Trickl et al. (2010, “TT2010”; light green).

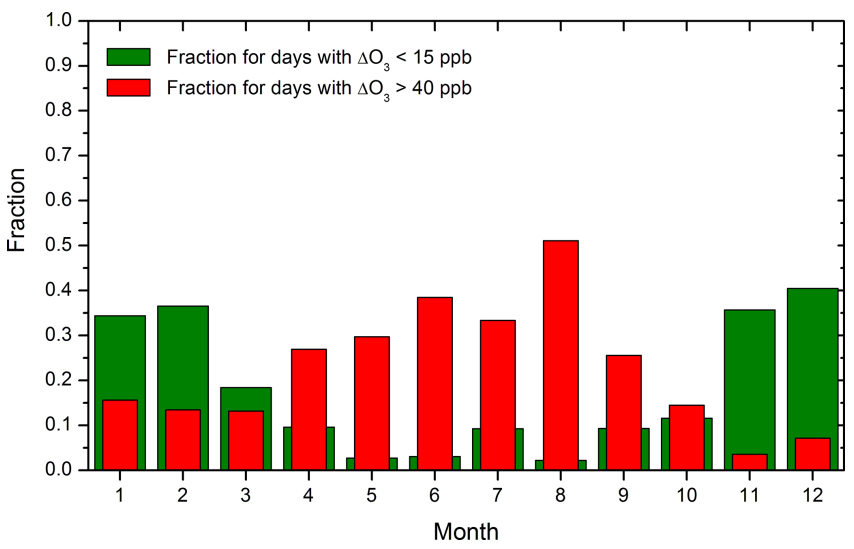

Figure 14. Fraction of intrusion days in the ozone lidar data with weak and strong ozone peaks averaged for each month between 2007 and 2016 (see text).

jet stream and co-incidence with an upper-level front was required. Apart from RH, where our approach is much stricter, all other thresholds are likely to reduce the fraction, and the product of all the partial fractions could, indeed, be rather small. The additional criteria could exclude many of the aged intrusions that originate over rather remote regions and dominate our observations in the middle and upper troposphere. For example, the trajectory results for Type- 6 intru- 
sions frequently yield a wind speed of the order of $1000 \mathrm{~km}$ in $24 \mathrm{~h}\left(11.6 \mathrm{~m} \mathrm{~s}^{-1}\right)$ during the approach to central Europe. One additional possibility is that the analysis of Beekmann et al. (1997) focussed just on isolated peaks, which could exclude some of the wider structures we observed in the middle and upper troposphere. In addition, a potential increase in STT frequency between the early 1990s and recent years must be considered. However, the Zugspitze in situ results (Fig. 1), which reveal most of the increase in deep STT that occurred between the 1970s and 2003, suggest that such a contribution is less important.

In contrast to this, as mentioned in the Introduction, Dibb et al. (2003) determined a huge fraction of stratospheric ozone from a large number of aircraft missions between Colorado and the Arctic Sea, up to more than $85 \%$. The analysis involved ${ }^{7} \mathrm{Be}$ as a tracer.

In summary, high stratospheric fractions have been reported for several stations and airborne measurements at different latitudes though not all around the year as in our data. This, together with other findings cited in the Introduction, indicate a much higher importance of STT than thought in work more than 2 decades ago. Similar analyses for significantly more stations at different latitudes are desirable. Some of the long-term sonde series such as Uccle, Hohenpeißenberg and Payerne should be analysed again with revised datafiltering criteria in order to make the results more comparable with more recent work.

The absence of a pronounced summer minimum in the free-tropospheric seasonal cycle in Fig. 13 as compared to the minimum in the Alpine summit-station data (Stohl et al., 2000; Fig. 1 in Trickl et al., 2010) suggests the existence of a summer maximum of transport pathways leading to the derived seasonal cycle. In addition to the summer maximum of the fractions (Fig. 13). Fig. 14 suggests a summer maximum of the ozone content in free-tropospheric intrusion layers, perhaps to some extent due to thicker layers separating from the lowermost stratosphere during the warm season. In fact, Trickl et al. (2014) concluded that most intrusions originate in the lowest layer above the dynamical tropopause. This was confirmed in the same paper by the almost negligible drop in Zugspitze CO in STT layers and was verified by LAGRANTO transport modelling of the LUAMI (Lindenberg upper-Air Methods Intercomparison) case (Trickl et al., 2016).

However, a robust estimate of the summertime ozone transfer from the stratosphere to the troposphere from our data is difficult since not all of the strongly elevated ozone above $4.5 \mathrm{~km}$ correlates with low humidity: the temporal overlap with the measurements with the water-vapour DIAL until the 2015 laser damage was frequently not sufficient, and the dry layers $(\mathrm{RH} \leq 10 \%)$ observed above the rather remote radiosonde stations rarely cover the full range of elevated ozone.

Diagnosing the elevated ozone above about $4.5 \mathrm{~km}$ in summer (Figs. 9, 10), where water vapour is also highly variable
(Vogelmann et al., 2015), requires a much more elaborate approach. Outside the dry layers quite frequently the source regions could not be identified due to missing ascent of the trajectories from the PBL within $315 \mathrm{~h}$ (HYSPLIT maximum) or no clear indication of descent from the stratosphere. Trickl et al. (2011), focussing on just six cases, found the occurrence of high-ozone upper-tropospheric air streams that originated from merging ascending and descending air masses along the subtropical jet stream. That study included calculations over 15 to $20 \mathrm{~d}$ with the FLEXPART model. Such a considerable effort has been beyond the scope of the current investigation based on an intense programme of routine measurements extended over many years. Just a crude estimate was made for a single year (2014), indicating a summertime stratospheric fraction of free-tropospheric ozone of the order of $26 \%$. This fraction does not include the longer-lived "indirect" stratospheric component that, due to mixing, cannot be identified from the observations available such as in the case of Fig. 1.

Certainly, improved modelling will be needed to quantify STT. So far, Eulerian models have had difficulties in reproducing the strong ozone rise at the Alpine sites (e.g. Parrish et al., 2014; Staehelin et al., 2017). The calculated ozone rise reported by Parrish et al. (2014) and Staehelin et al. (2017) ends almost 20 years earlier than the observed one. In Eulerian models higher spatial resolution is needed for reproducing deep STT (Roelofs et al., 2003; Trickl et al., 2010; Rastigejev et al., 2010; Eastham and Jacob, 2017) as well as reduced free-tropospheric mixing (Trickl et al., 2014). Due to the limited free-tropospheric mixing Lagrangian approaches look promising.

In any case, transport modelling must be extended to about $20 \mathrm{~d}$. This study has revealed that the transport pattern of the intrusions is dominated by slow descent from Canada, Alaska and Siberia (Type 6 as defined by Trickl et al., 2010). The trajectories frequently exhibit horizontally wavelike transport paths, but mostly without strong vertical variation. This kind of long-range descent, its underlying dynamics and its influence on the STT budget call for a meteorological explanation. It would also be interesting to determine how much an extension of the transport calculations to at least $15 \mathrm{~d}$ (as suggested by our analyses) would change the STT budget with respect to earlier work (e.g. Sprenger et al., 2003; Škerlak et al., 2014).

A great hope is the planned re-analysis of the Zugspitze ozone series by using the refined data-filtering criteria derived by Trickl et al. (2010). Here, additional information is available from the ${ }^{7} \mathrm{Be}$ measurements, and the in situ data do not exhibit a fair-weather bias. However, such an effort must also account for the source conditions: the tropopause region is a mixture of about $50 \%$ stratospheric and tropospheric air each (Shapiro, 1980; Vogel et al., 2011). The stratospheric portion of the descending air mass can vary significantly, also depending on the stratospheric residence time (Reiter et al., 1975). We find in our trajectory studies that not all 
air parcels stay in the lower stratosphere for a long period of time: Sometimes air masses descending to the Alps had stayed above the tropopause for less than a single day, after a pronounced rise even from low altitudes. All these facts also mean a challenge in future modelling efforts.

Data availability. The data can be obtained on request from the authors of this paper (thomas.trickl@kit.edu (thomas@trickl.de), hannes.vogelmann@kit.de, ludwig.ries@gawstat.de, michael.sprenger@env.ethz.ch). The 313 nm aerosol backscatter coefficients are archived in the EARLINET database, accessible through the ACTRIS data portal http://actris.nilu.no/, last access: 2 January 2020.

Author contributions. TT and HV carried out the lidar measurements. LR made available the in situ data for the Schneefernerhaus station. MS provided the operational daily STT forecasts with LAGRANTO as well as selected model runs based on re-analysis meteorological data. TT interpreted the observations and prepared the manuscript, assisted by the co-authors.

Competing interests. The authors declare that they have no conflict of interest.

Acknowledgements. The authors thank Hans Peter Schmid for his support. We are indebted to Hans-Eckhart Scheel who detected the importance of STT in the Zugspitze ozone in the late 1990s and set the motivation for our STT studies ever since. Due to his early death in 2013 he can no longer co-author this paper. They acknowledge the assistance by Helmuth Giehl and Matthias Perfahl as well as the great support by the UFS team. Wolfgang Steinbrecht provided ozone sonde data of the German Weather Service (DWD) for comparisons. Bradley Pierce helped us with an ozone analysis for the US. The development of the Zugspitze water-vapour DIAL has been funded by the Bavarian Ministry of Economics and German Bundesministerium für Bildung und Forschung within the programme Atmosphärenforschung 2000 (ATMOFAST project: Atmospheric Long-range Transport and its Impact on the Trace-gas Composition in the Free Troposphere over Central Europe, (ATMOFAST, 2005)). The aerosol observations contribute to EARLINET (European Aerosol Research Lidar Network, currently partly founded by ACTRIS 2).

Financial support. The article processing charges for this openaccess publication were covered by a Research Centre of the Helmholtz Association.

Review statement. This paper was edited by Evangelos Gerasopoulos and reviewed by two anonymous referees.

\section{References}

ATMOFAST: Atmosphärischer Ferntransport und seine Auswirkungen auf die Spurengaskonzentrationen in der freien Troposphäre über Mitteleuropa (Atmospheric Long-range Transport and its Impact on the Trace-gas Composition of the Free Troposphere over Central Europe), Project Final Report, edited by: Trickl, T., Kerschgens, M., Stohl, A., and Trickl, T., funded by the German Ministry of Education and Research within the programme "Atmosphärenforschung 2000", http://www.trickl.de/ATMOFAST.htm (last access: 2 January 2020), 130 pp., 2005 (in German).

Beekmann, M., Ancellet, G., Blonsky, S., De Muer, D., Ebel, A., Elbern, H., Hendricks, J., Kowol, J., Mancier, C., Sladkovic, R., Smit, H. G. J., Speth, P., Trickl, T., and Van Haver, P.: Regional and Global Tropopause Fold Occurrence and Related Ozone Flux across the Tropopause, J. Atmos. Chem., 28, 29-44, 1997.

Browell, E. V., Danielsen, E. F., Ismail, S., Gregory, G. L., and Beck, S. M.: Tropopause Fold Structure Determined from Airborne Lidar and in Situ Measurements, J. Geophys. Res., 92, 2112-2120, 1987.

Cammas, J.-P., Jacoby-Koaly, S., Suhre, K., Rosset, R., and Marenco, A.: Atlantic subtropical potential vorticity barrier of Ozone by Airbus In-Service Aircraft (MOZAIC) flights, J. Geophys. Res., 103, 25681-25693, 1998.

Carnuth, W. and Trickl, T.: Transport studies with the IFU threewavelength aerosol lidar during the VOTALP Mesolcina experiment, Atmos. Environ., 34, 1425-1434, 2000.

Carnuth, W., Kempfer, U., and Trickl, T.: Highlights of the Tropospheric Lidar Studies at IFU within the TOR Project, Tellus B, 54, 163-185, 2002.

Colette, A. and Ancellet, G.: Impact of vertical transport processes on the tropospheric ozone layering above Europe, Part II: Climatological analysis of the past 30 years, Atmos. Environ., 39, 5423-5435, 2005.

Collins, W. J., Derwent, R. G., Garnier, B., Johnson, C. E., Sanderson, M. G., and Stevenson, D. S.: Effect of stratospheretroposphere exchange on the future ozone trend, J. Geophys. Res., 108, 8528, https://doi.org/10.1029/2002JD002617, 2003.

Cooper, O., Forster, C., Parrish, D., Dunlea, E., Hübler, G., Fehsenfeld, F., Holloway, J., Oltmans, S., Johnson, B., Wimmers, A., and Horowitz, L.: On the life cycle of a stratospheric intrusion and its dispersion into polluted warm conveyor belts, J. Geophys Res., 109, D23S09, https://doi.org/10.1029/2003JD004006, 2004.

Cristofanelli, P., Scheel, H.-E., Steinbacher, M., Saliba, M., Azzopardi, F., Ellul, R., Fröhlich, M., Tositti, L., Brattich, E., Maione, M., Calzolari, F., Duchi, F., Landi, T. C., Marinoni, A., and Bonasoni, P.: Long-term surface ozone variability at Mt. Cimone WMO/GAW global station (2165 m a.s.l., Italy), Atmos. Environ., 101, 23-33, 2015.

Danielsen, E. F.: Stratospheric-Tropospheric Exchange Based on Radioactivity, Ozone and Potential Vorticity, J. Atmos. Sci., 25, 505-518, 1968.

Danielsen, E. F. and Mohnen, V. A.: Project Dustorm Report: Ozone Transport, in Situ Measurements, and Meteorological Analyses of Tropopause Folding, J. Geophys. Res., 82, 5867-5877, 1977.

Dee, D. P., Uppala, S. M., Simmons, A. J., Berrisford, P., Poli, P., Kobayashi, S., Andrae, U., Balmaseda, M. A., Balsamo, G., Bauer, P., Bechtold, P., Beljaars, A. C. M., van de Berg, L., Bid- 
lot, J., Bormann, N., Delsol, C., Dragani, R., Fuentes, M., Geer, A. J., Haimberger, L., Healy, S. B., Hersbach, H., Hólm, E. V., Isaksen, L., Kållberg, P., Köhler, M., Matricardi, M., McNally, A. P., Monge-Sanz, B. M., Morcrette, J.-J., Park, B.-K., Peubet, C., de Rosnay, P., Tavolato, C., Thépaut, J.-N., and Vitard, F.: The ERA-Interim reanalysis: Configuration and performance of the data assimilation system, Q. J. Roy. Meteor. Soc., 137, 553-597, 2011.

Deshler, T.: A review of global stratospheric aerosol: Measurements, importance, life cycle, and local stratospheric aerosol, Atmos. Res., 90, 223-232, 2008.

Dibb, J. E., Talbot, R. W., Scheuer, E., Seid, G., DeBell, L., Lefer, B., and Ridley, B.: Stratsopheric influence on the northern North American free troposphere during TOPSE, J. Geophys. Res., 108, 8363, https://doi.org/10.1029/2001JD001347, 2003.

Draxler, R. and Hess, G.: An overview of the HYSPLIT_4 modelling system for trajectories, dispersion, and deposition, Aust. Meteorol. Mag., 47, 295-308, 1998.

EARLINET: A European Aerosol Research Lidar Network to Establish an Aerosol Climatology, Final Report, European Union, contract EVR1-CT1999-40003, edited by: Bösenberg, J. and Matthias, V., Reporting Period February 2000 to February 2003, Max-Planck-Institut für Meteorologie, Hamburg (Germany), Report No. 348, ISSN 0937 1060, 212 pp., 2003.

Eastham, S. D. and Jacob, D. J.: Limits on the ability of global Eulerian models to resolve intercontinental transport of chemical plumes, Atmos. Chem. Phys., 17, 2543-2553, https://doi.org/10.5194/acp-17-2543-2017, 2017.

Eisele, H. and Trickl, T.: Second Generation of the IFU Stationary Tropospheric Ozone Lidar, in: Advances in: Atmospheric Remote Sensing with Lidar, Selected Papers of the 18th International Laser Radar Conference, Berlin (Germany), 22-26 July 1996, edited by: Ansmann, A., Neuber, R., Rairoux, P., and Wandinger, U., Springer, Berlin, Heidelberg, Germany, 379-382, 1997.

Eisele, H. and Trickl, T.: Improvements of the aerosol algorithm in ozone-lidar data processing by use of evolutionary strategies, Appl. Opt., 44, 2638-2651, 2005.

Eisele, H., Scheel, H. E., Sladkovic, R., and Trickl, T.: Highresolution Lidar Measurements of Stratosphere-troposphere Exchange, J. Atmos. Sci., 56, 319-330, 1999.

Elbern, H., Kowol, J., Sladkovic, R., and Ebel, A.: Deep stratospheric intrusions: A statistical assessment with model guided analysis, Atmos. Environ., 31, 3207-3226, 1997.

Fromm, M., Shettle, E. P., Fricke, K. H., Ritter, C., Trickl, T., Giehl, H., Gerding, M., Barnes, J., O’Neill, M., Massie, S. T., Blum, U., McDermid, I. S., Leblanc, T., and Deshler, T.: The stratospheric impact of the Chisholm PyroCumulonimbus eruption: 2. Vertical profile perspective, J. Geophys. Res., 113, D08203, https://doi.org/10.1029/2007JD009147, 2008.

Fromm, M., Lindsey, D. T., Servranckx, R., Yue, G., Trickl, T., Sica, R., Doucet, P., and Godin-Beekmann, S.: The Untold Story of Pyrocumulonimbus, B. Am. Meterol. Soc., 91, 1193-1209, 2010.

Gaudel, A., Cooper, O. R., Ancellet, G., Barret, B., Boynard, A., Burrows, J. P., Clerbaux, C., Coheur, P.-F., Cuesta, J., Cuevas, E., Doniki, S., Dufour, G., Ebojie, F., Foret, G., Garcia, O., Granados-Muñoz, M. J., Hannigan, J., Hase, F., Hassler, B., Huang, G., Hurtmans, D., Jaffe, D., Jones, N., Kalabokas, P., Kerridge, B., Kulawik, S., Latter, B., Leblanc, T., Le Flochmoën,
E., Lin, W., Liu, J., Liu, X., Mahieu, E., McClure-Begley, A., Neu, J., Osman, M., Palm, M., Petetin, H., Petropavlovskikh, I., Querel, R., Rahpoe, N., Rozanov, A., Schultz, M. G., Schwab, J., Siddans, R., Smale, D., Steinbacher, M., Tanimoto, H., Tarasick, D., Thouret, V., Thompson, A. M., Trickl, T., Weatherhead, E., Wespes, C., Worden, H., Vigouroux, C., Xu, X., Zeng, G., and Ziemke, J.: Tropospheric Ozone Assessment Report: Present-day distribution and trends of tropospheric ozone relevant to climate and global atmospheric chemistry model evaluation, Elem. Sci. Anth., 6, 39, https://doi.org/10.1525/elementa.291, 2018.

Gouget, H., Cammas, J.-P., Marenco, A., Rosset, R., and Jonquières, I.: Ozone peaks associated with a subtropical tropopause fold and with the trade wind inversion: A case study from the airborne campaign TROPOZ II over the Caribbean in winter, J. Geophys. Res., 101, 25979-25993, 1996.

Granados-Muñoz, M. J. and Leblanc, T.: Tropospheric ozone seasonal and long-term variability as seen by lidar and surface measurements at the JPL-Table Mountain Facility, California, Atmos. Chem. Phys., 16, 9299-9319, https://doi.org/10.5194/acp16-9299-2016, 2016.

Huh, C. A. and Liu, L. G.: Precision measurements of the half-lives of some electron-capture decay nuclides: ${ }^{7} \mathrm{Be},{ }^{54} \mathrm{Mn},{ }^{83} \mathrm{Rb}$, and ${ }^{84}$ Rb, J. Radioanal. Nucl. Ch., 246, 229-231, 2000.

Jaeglé, L., Wood, R., and Wargan, K.: Multiyear composite view of ozone enhancements and stratosphere-to-troposphere transport in dry intrusions of northern hemisphere extratropical cyclones, J. Geophys. Res., 122, 13436-13457, https://doi.org/10.1002/2017JD027656, 2017.

Jäger, H., Carnuth, W., and Georgi, B.: Observations of Saharan Dust at a North Alpine Station, J. Aerosol Sci., 19, 1235-1238, 1988.

James, P., Stohl, A., Forster, C., Eckhardt, S., Seibert, P., and Frank, A.: A 15-year climatology of stratosphere-troposphere exchange with a Lagrangian particle dispersion model 2. Mean climate and seasonal variability, J. Geophys. Res., 108, 8522, https://doi.org/10.1029/2002JD002639, 2003,

Jonson, J. E., Simpson, D., Fagerli, H., and Solberg, S.: Can we explain the trends in European ozone levels?, Atmos. Chem. Phys., 6, 51-66, https://doi.org/10.5194/acp-6-51-2006, 2006.

Kempfer, U., Carnuth, W., Lotz, R., and Trickl, T.: A Wide-range UV Lidar System for Tropospheric Ozone Measurements: Development and Application, Rev. Sci. Instrum., 65, 3145-3164, 1994.

Kentarchos, A. S. and Roelofs, G. J.: A model study of stratospheric ozone in the troposphere and its contribution to tropospheric $\mathrm{OH}$ formation, J. Geophys. Res., 108, 8517, https://doi.org/10.1029/2002JD002598, 2003.

Koch, P., Wernli, H., and Davies, H. C.: An Event-based Jet-stream Climatology and Typology, Int. J. Climatol., 26, 283-301, 2006.

Kowol-Santen, J. and Ancellet, G.: Mesoscale analysis of transport across the subtropical tropopause, Geophys. Res. Lett., 27, 33453348, 2000.

Kuang, S., Newchurch, M. J., Thompson, A. M., Stauffer, R. M., Johnson, B. J., and Wang, L.: Ozone Variability and Anomalies Observed During SENEX and SEAC ${ }^{4}$ RS Campaigns in 2013, J. Geophys. Res., 122, 11227-11241, 2017.

Lal, D. and Peters, B.: Cosmic Ray Produced Radioactivity on the Earth, Handb. Phys., 46, 551-612, 1967. 
Langford, A. O.: Stratosphere-troposphere exchange at the subtropical jet, contribution to the tropospheric ozone budget at midlatitudes, Geophys. Res. Lett, 26, 2449-2452, 1999.

Langford, A. O., Brioude, J., Cooper, O. R., Senff, C. J., Alvarez II, R. J., Hardesty, R. M., Johnson, B. J., and Oltmans, S. J.: Stratospheric influence on surface ozone in the Los Angeles area during late spring and early summer of 2010, J. Geophys. Res., 117, D00V06, https://doi.org/10.1029/2011JD016766, 2012.

Lefohn, A. S., Wernli, H., Oltmans, S. J., and Shapiro, M.: The importance of stratospheric-tropospheric transportin affecting surface ozone concentrations in the western and northern tier of the United States, Atmos. Environ., 45, 4845-4857, 2011.

Lin, M., Fiore, A. M., Cooper, O. R., Horowitz, L. W., Langford, A. O., Levy II, H., Johnson, B. J., Naik, V., Oltmans, S. J., and Senff, C. J.: Springtime high surface ozone events over the western United States: Quantifying the role of stratospheric intrusions, J. Geophys. Res., 117, D00V22, https://doi.org/10.1029/2012JD018151, 2012.

Lin, M., Fiore, A. M., Horowitz, L. W., Langford, A. O., Oltmans, S. J., Tarasick, D., and Rieder, H. E.: Climate variability modulates western US ozone air quality in spring via deep stratospheric intrusions, Nat. Commun., 6, 7105, https://doi.org/10.1038/ncomms8105, 2015.

Logan, J. A., Staehelin, J., Megretskaia, I. A., Cammas, J.P., Thouret, V., Claude, H., De Backer, H., Steinbacher, M., Scheel, H.-E., Stübi, R., Fröhlich, M., and Derwent, R.: Changes in ozone over Europe: Analysis of ozone measurements from sondes, regular aircraft (MOZAIC) and alpine surface sites, J. Geophys. Res., 117, D09301, https://doi.org/10.1029/2011JD016952, 2012.

Madonna, E., Wernli, H., Joos, H., and Martius, O.: Warm Conveyor Belts in the ERA-Interim Dataset (1979-2010), Part I: Climatology and Potential Vorticity Evolution, J. Clim., 27, 3-26, 2014.

Marenco, A., Gouget, H., Nédélec, P., Pagés, J.-P., and Karcher, F.: Evidence of a long-term increase in tropospheric ozone from Pic du Midi data series: Consequences: Positive radiative forcing, J. Geophys. Res., 99, 16617-16632, 1994.

Marenco, A., Thouret, V., Nédélec, P., Smit, H., Helten, M., Kley, D., Karcher, F., Simon, P., Law, K., Pyle, J., Poschmann, G., Von Wrede, M., Hume, C., and Cook, T.: Measurement of ozone and water vapor by Airbus in-service aircraft: The MOZAIC airborne program, An overview, J. Geophys. Res., 103, 25631-25642, 1998.

Miloshevich, L. M., Vömel, H., Whiteman, D. N., Lesht, B. M., Schmidlin, F. J., and Russo, F.: Absolute accuracy of water vapour measurements from six operational radiosonde types launched during AWEX-G and implications for AIRS validation, J. Geophys. Res., 111, D09S10, https://doi.org/10.1029/2005JD006083, 2006.

Neu, J. L., Flury, T., Manney, G. L., Santee, M. L., Livesey, N. J., and Worden, J.: Tropospheric ozone variations governed by changes in stratospheric circulation, Nat. Geosci., 7, 340-344, 2014

Newell R. E., Thouret, V., Cho, J. Y. N., Stoller, P., Marenco, A., and Smit, H. G. J.: Ubiquity of quasi-horizontal layers in the troposphere, Nature, 398, 316-319, 1999.

Nyeki, S., Kalberer, M., Kolbeck, I., De Wekker, S., Furger, M., Gäggeler, W., Kossmann M., Lugauer, M., Steyn, D., Weingartner, E., Wirth, M., and Baltensperger, U.: Convective Boundary
Layer Evolution to $4 \mathrm{~km}$ asl over High-AlpineTerrain: Airborne Lidar Observations in the Alps, Geophys. Res. Lett, 27, 689-692, 2000.

Ojha, N., Naja, M., Sarangi, T., Kumar, R., Bhardway, R., Lal, S., Venkataramani, S., Sagar, R., Kumar, A., and Chandola, H. C.: on the processes influencing the vertical distribution of ozone over the central Himalayas: Analysis of yearlong ozonesonde observations, Atmos. Environ., 88, 201-211, 2014.

Ojha, N., Pozzer, A., Akritidis, D., and Lelieveld, J.: Secondary ozone peaks in the troposphere over the Himalayas, Atmos. Chem. Phys., 17, 6743-6757, https://doi.org/10.5194/acp-176743-2017, 2017.

Oltmans, S. J., Lefohn, A. S., Harris, J. M., Galbally, I., Scheel, H. E., Bodeker, G., Brunke, E., Claude, H., Tarasick, D., Johnson, B. J., Simmonds, P., Shadwick, D., Anlauf, K., Hayden, K., Schmidlin, F., Fujimoto, F., Akagi, K., Meyer, C., Nichol, S., Davies, J., Redondas, A., and Cuevas, E.: Long-term changes in tropospheric ozone, Atmos. Environ., 40, 3156-3173, 2006.

Oltmans, S. J., Lefohn, A. S., Shadwick, D., Harris, J. M., Scheel, H. E., Galbally, I., Tarasick, D. W., Johnson, B. J., Brunke, E.G., Claude, H., Zeng, G., Nichol, S., Schmidlin, F., Davies, J., Cuevas, E., Redondas, A., Naoe, H., Nakano, T., and Kawasato, T.: Recent tropospheric ozone changes - A pattern dominated by slow or no growth, Atmos. Environ., 67, 331-351, 2012.

Ordoñez, C., Brunner, D., Staehelin, J., Hadjinicolaou, P., Pyle, J. A., Jonas, M., Wernli, H., and Prévôt, A. S. H.: Strong influence of lowermost stratospheric ozone on lower tropospheric background ozone changes over Europe, Geophys. Res. Lett., 34, L07805, https://doi.org/10.1029/2006GL029113, 2007.

Ott, L. E., Duncan, B. N., Thompson, A. M., Diskin, G., Fasnacht, Z., Langford, A. O., Lin, M., Molod, A. M., Nielsen, J. E., Pusede, S. E., Wargan, K., Weinheimer, A. J., and Yoshida, Y.: Frequency and impact of summertime stratospheric intrusions over Maryland during DISCOVER-AQ (2011): New evidence from NASA's GEOS-5 simulations, J. Geophys. Res., 121, 36873706, https://doi.org/10.1002/2015JD024052, 2016.

Papayannis, A., Amiridis, V., Mona, L., Tsaknakis, G., Balis, D., Bösenberg, J., Chaikovski, A. De Tomasi, F., Grigorov, I., Mattis, I., Mitev, V., Müller, D., Nickovic, S., Pérez, C., Pietruczuk, A. Pisani, G., Ravetta, F., Rizi, V., Sicard, M., Trickl, T., Wiegner, M., Gerding, M., Mamouri, R. E., D’ Amico, G., and Pappalardo, G.: Systematic lidar observations of Saharan dust over Europe in the frame of EARLINET (2000-2002), J. Geophys. Res., 113, D10204, https://doi.org/10.1029/2007JD009028, 2008.

Parrish, D. D., Singh, H. B., Molina, L., and Madronich, S.: Air quality progress in North American megacities: A review, Atmos. Environ., 45, 7015-7025, 2011.

Parrish, D. D., Law, K. S., Staehelin, J., Derwent, R., Cooper, O. R., Tanimoto, H., Volz-Thomas, A., Gilge, S., Scheel, H.-E., Steinbacher, M., and Chan, E.: Long-term changes in lower tropospheric baseline ozone concentrations at northern mid-latitudes, Atmos. Chem. Phys., 12, 11485-11504, https://doi.org/10.5194/acp-12-11485-2012, 2012.

Parrish, D. D., Lamarque, J.-F., Naik, V., Horowitz, L., Shindell, D. T., Staehelin, J., Derwent, R., Cooper, O. R., Tanimoto, H., Volz-Thomas, A., Gilge, S., Scheel., H.-E., Steinbacher, M., and Fröhlich, M.: Long-term changes in lower tropospheric baseline ozone concentrations: Comparing chemistry-climate models 
and observations at northern midlatitudes, J. Geophys. Res., 119, 5719-5736, https://doi.org/10.1002/2013JD021435, 2014.

Parrish, D. D., Xu, J., Croes, B., and Shao, M.: Air quality improvement in Los Angeles perspectives for developing cities, Front. Environ. Sci. Eng., 10, 11, https://doi.org/10.1007/s11783-0160859-5, 2016.

Rastigejev, Y., Park, R., Brenner, M., and Jacob, D.: Resolving intercontinental pollution plumes in global models of atmospheric transport, J. Geophys. Res., 115, D02302, https://doi.org/10.1029/2009JD012568, 2010.

Reiter, R.: The ozone trend in the layer of 2 to $3 \mathrm{~km}$ a.s.l. since 1978 and the typical time variations of the ozone profile between ground and $3 \mathrm{~km}$ a.s.1., Meteorol. Atmos. Phys., 42, 91104, 1990.

Reiter, E. R., Carnuth, W., Kanter, H.-J., Pötzl, K., Reiter, R., and Sládkovič, R.: Measurements of Stratospheric Residence Times, Arch. Met. Geoph. Biokl. A, 24, 41-51, 1975.

Reiter, R., Sladkovic, R., and Kanter, H.-J.: Concentration of Trace Gases in the Lower Troposphere, Simultaneously Recorded at Neighboring Mountain Stations, Part II: Ozone, Meteorol. Atmos. Phys., 37, 27-47, 1987.

Roelofs G.-J. and Lelieveld, J.: Model study of the influence of cross-tropopause $\mathrm{O}_{3}$ transports on tropospheric $\mathrm{O}_{3}$ levels, Tellus B, 49, 38-55, 1997.

Roelofs, G. J., Kentarchos, A. S., Trickl, T., Stohl, A., Collins, W. J., Crowther, R. A., Hauglustaine, D., Klonecki, A., Law, K. S., Lawrence, M. G., von Kuhlmann, R., and van Weele, M.: Intercomparison of tropospheric ozone models: Ozone transport in a complex tropopause folding event, J. Geophys. Res., 108, 8529, https://doi.org/10.1029/2003JD003462, 2003.

Scheel, H. E.: Ozone Climatology Studies for the Zugspitze and Neighbouring Sites in the German Alps, in: Tropospheric Ozone Research 2, EUROTRAC-2 Subproject Final Report, edited by: Lindskog, A., EUROTRAC International Scientific Secretariat, München, Germany, 134-139, 2003.

Scheel, H. E., Areskoug, H., Geiß, H., Gomiscek, B., Granby, K., Haszpra, L., Klasinc, L., Kley, D., Laurila, T., Lindskog, A., Roemer, M., Schmitt, R., Simmonds, P., Solberg, S., and Toupance, G.: On the Spatial Distribution and Seasonal Variation of LowerTropospheric Ozone over Europe, J. Atmos. Chem., 28, 11-28, 1997.

Shapiro, M. A.: Turbulent Mixing within Tropopause Folds as a Mechanism for the Exchange of Chemical Constituents between the Stratosphere and Troposphere, J. Atmos. Sci., 37, 994-1004, 1980.

Škerlak, B., Sprenger, M., and Wernli, H.: A global climatology of stratosphere-troposphere exchange using the ERA-Interim data set from 1979 to 2011, Atmos. Chem. Phys., 14, 913-937, https://doi.org/10.5194/acp-14-913-2014, 2014.

Sprenger, M. and Wernli, H.: The LAGRANTO Lagrangian analysis tool - version 2.0, Geosci. Model Dev., 8, 2569-2586, https://doi.org/10.5194/gmd-8-2569-2015, 2015.

Sprenger, M., Croci Maspoli, M., and Wernli, H.: Tropopause folds and cross-tropopause exchange: A global investigation based upon ECMWF analyses for the time period March 2000 to February 2001, J. Geophys. Res., 108, 8518, https://doi.org/10.1029/2002JD002587, 2003.

Sprenger, M., Fragkoulidis, G., Binder, H., Croci-Maspoli, M., Graf, P., Grams, C. M., Knippertz, P., Madonna, E., Schemm,
S., Škerlak, B., and Wernli, H.: Global Climatologies of Eulerian and Lagrangian Flow Features based on ERA-Interim, B. Am. Meteorol. Soc., 98, 1739-1748, 2017.

Staehelin, J. Tummon, F., Revell, L., Stenke, A., and Peter, T.: Tropospheric Ozone at Northern Mid-Latitudes: Modeled and Measured Long-Term Changes, Atmosphere, 8, 20 pp., 2017.

Stein, A. F., Draxler, R. R, Rolph, G. D., Stunder, B. J. B., Cohen, M. D., and Ngan, F.: NOAA's HYSPLIT atmospheric transport and dispersion modeling system, B. Am. Meteorol. Soc., 96, 2059-2077, 2015.

Steinbrecht, W., Claude, H., Schönenborn, F., Leiterer, U., Dier, H., and Lanzinger, E.: Pressure and Temperature Differences between Vaisala RS80 and RS92 Radiosonde Systems, J. Atmos. Ocean. Technol., 25, 909-927, 2008.

Stevenson, D. S., Dentener, F. J., Schultz, M. G., Ellingsen, K., van Noije, T. P. C., Wild, O., Zeng, G., Amann, M., Atherton, C. S., Bell, N., Bergmann, D. J., Bey, I., Butler, T., Cofala, J., Collins, W. J., Derwent, R. G., Doherty, R,. M., Drevet, J., Eskes, H. J., Fiore, A. M., Gauss, M,., Hauglustaine, D. A., Horowitz, L. W., Isaksen, I. S. A., Krol, M. C., Lamarque, J.-F., Lawrence, M. G., Montanaro, V., Müller, J.-F., Pitari, G., Prather, M. J., Pyle, J. A., Rast, S., Rodriguez, J. M., Sanderson, M. G., Savage, N. H., Shindell, D. T., Strahan, S. E., Sudo, K., and Szopa, S.: Multimodel ensemble simulations of present-day and near-future tropospheric ozone, J. Geophys. Res., 111, D08301, https://doi.org/10.1029/2005JD006338, 2006.

Stohl, A. and Seibert, P.: Accuracy of trajectories as determined from the conservation of meteorological tracers, Q. J. Roy. Meteor. Soc., 124, 1465-1484, 1998.

Stohl, A. and Trickl, T.: A textbook example of long-range transport: Simultaneous observation of ozone maxima of stratospheric and North American origin in the free troposphere over Europe, J. Geophys. Res., 104, 30445-30462, 1999.

Stohl, A., Spichtinger-Rakowsky, N., Bonasoni, P., Feldmann, H., Memmesheimer, M., Scheel, H. E., Trickl, T., Hübener, S., Ringer, W., and Mandl, M.: The influence of stratospheric intrusions on alpine ozone concentrations, Atmos. Environ., 34, 1323-1354, 2000.

Stohl, A., Bonasoni, P., Cristofanelli, P., Collins, W., Feichter, J., Frank, A., Forster, C., Gerasopoulos, E., Gäggeler, H., James, P., Kentarchos, T., Kromp-Kolb, H., Krüger, B., Land, C., Meloen, J., Papayannis, A., Priller, A., Seibert, P., Sprenger, M., Roelofs, G. J., Scheel, H. E., Schnabel, C., Siegmund, P., Tobler, L., Trickl, T., Wernli, H., Wirth, V., Zanis, P., and Zerefos, C.: Stratosphere-troposphere exchange - a review, and what we have learned from STACCATO, J. Geophys. Res., 108, 8516, https://doi.org/10.1029/2002JD002490, 2003.

Suhre, K., Cammas, J.-P., Nédélec, P., Rosset, R., Marenco, A., and Smit, H. G. J.: Ozone-rich transients in the upper equatorial Atlantic troposphere, Nature, 388, 661-663, 1997.

Tarasick, D., Galbally, I. E., Cooper, O. R., Schultz, M. G., Ancellet, G., Leblanc, T., Wallington, T. J., Ziemke, J., Liu, X., Steinbacher, M., Staehelin, J., Vigouroux, C., Hannigan, J., García, O., Foret, G., Zanis, P., Weatherhead, E., Petropavlovskikh, I., Worden, H., Osman, M., Liu, J., Chang, K.-L., Gaudel, A., Lin, M., Granados-Muñoz, M., Thompson, A. M., Oltmans, S. J., Cuesta, J., Dufour, G., Thouret, V., Hassler, B., Trickl, T., and Neu, J. L.: Tropospheric Ozone Assessment Report: Tropospheric ozone from 1877 to 2016, observed lev- 
els, trends and uncertainties, Elem. Sci. Anth., 7, 72 pp., https://doi.org/10.1525/elementa.376, 2019a.

Tarasick, D. W., Carey-Smith, T. K., Hocking, W. K., Moeini, O., He, H., Liu, J., Osman, M., Thompson, A. M. Johnson, B., Oltmans, S. J., and Merrill, J. T.: Quantifying stratospheretroposphere transport of ozone using balloon-borne ozonesondes, radar windprofilers and trajectory models, Atmos. Environ., 198, 496-509, 2019b.

Thouret, V., Cho, J. Y. N., Newell R. E., Marenco, A., and Smit, H. G. J.: General characteristics of tropospheric constituent layers observed in the MOZAIC program, J. Geophys. Res., 105, 17379-17392, 2000

Trickl, T., Cooper, O. C., Eisele, H., James, P., Mücke, R., and Stohl, A.: Intercontinental transport and its influence on the ozone concentrations over central Europe: Three case studies, J. Geophys. Res., 108, 8530, https://doi.org/10.1029/2002JD002735, 2003.

Trickl, T., Feldmann, H., Kanter, H.-J., Scheel, H.-E., Sprenger, M., Stohl, A., and Wernli, H.: Forecasted deep stratospheric intrusions over Central Europe: case studies and climatologies, Atmos. Chem. Phys., 10, 499-524, https://doi.org/10.5194/acp-10499-2010, 2010.

Trickl, T., Bärtsch-Ritter, N., Eisele, H., Furger, M., Mücke, R., Sprenger, M., and Stohl, A.: High-ozone layers in the middle and upper troposphere above Central Europe: potential import from the stratosphere along the subtropical jet stream, Atmos. Chem. Phys., 11, 9343-9366, https://doi.org/10.5194/acp11-9343-2011, 2011.

Trickl, T., Giehl, H., Jäger, H., and Vogelmann, H.: 35 yr of stratospheric aerosol measurements at Garmisch-Partenkirchen: from Fuego to Eyjafjallajökull, and beyond, Atmos. Chem. Phys., 13, 5205-5225, https://doi.org/10.5194/acp-13-5205-2013, 2013.

Trickl, T., Vogelmann, H., Giehl, H., Scheel, H.-E., Sprenger, M., and Stohl, A.: How stratospheric are deep stratospheric intrusions?, Atmos. Chem. Phys., 14, 9941-9961, https://doi.org/10.5194/acp-14-9941-2014, 2014.

Trickl, T., Vogelmann, H., Flentje, H., and Ries, L.: Stratospheric ozone in boreal fire plumes - the 2013 smoke season over central Europe, Atmos. Chem. Phys., 15, 9631-9649, https://doi.org/10.5194/acp-15-9631-2015, 2015.

Trickl, T., Vogelmann, H., Fix, A., Schäfler, A., Wirth, M., Calpini, B., Levrat, G., Romanens, G., Apituley, A., Wilson, K. M., Begbie, R., Reichardt, J., Vömel, H., and Sprenger, M.: How stratospheric are deep stratospheric intrusions? LUAMI 2008, Atmos. Chem. Phys., 16, 8791-8815, https://doi.org/10.5194/acp16-8791-2016, 2016.

Viezee, W., Johnson, W. B., and Singh, H. B.: Stratospheric Ozone in the Lower Troposphere - II. Assessment of Downward Flux and Ground-Level Impact, Atmos. Environ., 17, 1979-1993, 1983.

Vautard, R., Szopa, S., Beekmann, M., Menut, L., Hauglustaine, D. A., Rouil, L., and Roemer, M.: Are decadal anthropogenic emission reductions in Europe consistent with surface ozone observations?, Geophys. Res. Lett., 33, L13810, https://doi.org/10.1029/2006GL026080, 2006.

Vogel, B., Pan, L. L., Konopka, P., Günther, G., Müller, R., Hall, W., Campos, T., Pollack, I., Weinheimer, A., Wei, J., Atlas, E. L., and Bowman, K. P.: Transport Pathways and signatures of mixing in the extratropical tropopause region derived from La- grangian model simulations, J. Geophys. Res., 116, D05306, https://doi.org/10.1029/2010JD014876, 2011.

Vogelmann, H. and Trickl, T.: Wide-Range Sounding of FreeTropospheric Water Vapor with a Differential-Absorption Lidar (DIAL) at a High-Altitude Station, Appl. Opt., 47, 2116-2132, 2008.

Vogelmann, H., Sussmann, R., Trickl, T., and Borsdorff, T.: Intercomparison of atmospheric water vapor soundings from the differential absorption lidar (DIAL) and the solar FTIR system on Mt. Zugspitze, Atmos. Meas. Tech., 4, 835-841, https://doi.org/10.5194/amt-4-835-2011, 2011.

Vogelmann, H., Sussmann, R., Trickl, T., and Reichert, A.: Spatiotemporal variability of water vapor investigated using lidar and FTIR vertical soundings above the Zugspitze, Atmos. Chem. Phys., 15, 3135-3148, https://doi.org/10.5194/acp-153135-2015, 2015.

Volz, A. and Kley, D.: Evaluation of the Montsouris series of ozone measurements made in the nineteenth century, Nature, 332, 240 242, 1988.

Wandinger, U., Freudenthaler, V., Baars, H., Amodeo, A., Engelmann, R., Mattis, I., Groß, S., Pappalardo, G., Giunta, A., D’Amico, G., Chaikovsky, A., Osipenko, F., Slesar, A., Nicolae, D., Belegante, L., Talianu, C., Serikov, I., Linné, H., Jansen, F., Apituley, A., Wilson, K. M., de Graaf, M., Trickl, T., Giehl, H., Adam, M., Comerón, A., Muñoz-Porcar, C., Rocadenbosch, F., Sicard, M., Tomás, S., Lange, D., Kumar, D. Pujadas, M., Molero, F., Fernández, A. J., Alados-Arboledas, L., Bravo-Aranda, J. A., Navas-Guzmán, F., Guerrero-Rascado, J. L., Granados-Muñoz, M. J., Preißler, J., Wagner, F., Gausa, M., Grigorov, I., Stoyanov, D., Iarlori, M., Rizi, V., Spinelli, N., Boselli, A., Wang, X., Lo Feudo, T., Perrone, M. R., De Tomasi, F., and Burlizzi, P.: EARLINET instrument intercomparison campaigns: overview on strategy and results, Atmos. Meas. Tech., 9, 1001-1023, https://doi.org/10.5194/amt-9-1001-2016, 2016.

Wernli, H.: A Lagrangian-based analysis of extratropical cyclones, II: A detailed case study, Q. J. Roy. Meteor. Soc., 123, 16771706, 1997.

Wernli, H. and Davies, H. C.: A Lagrangian-based analysis of extratropical cyclones, I. The method and some applications, Q. J. Rpy. Meteor. Soc., 123, 467-489, 1997.

Wild, O.: Modelling the global tropospheric ozone budget: exploring the variability in current models, Atmos. Chem. Phys., 7, 2643-2660, https://doi.org/10.5194/acp-7-2643-2007, 2007.

Yang, H., Chen, G., Tang, Q., and Hess. P.: Quantifying isentropic stratosphere-troposphere exchange of ozone, J. Geophys. Res., 121, 3372-3385, https://doi.org/10.1002/2015JD024180, 2016.

Young, P. J., Archibald, A. T., Bowman, K. W., Lamarque, J.-F., Naik, V., Stevenson, D. S., Tilmes, S., Voulgarakis, A., Wild, O., Bergmann, D., Cameron-Smith, P., Cionni, I., Collins, W. J., Dalsøren, S. B., Doherty, R. M., Eyring, V., Faluvegi, G., Horowitz, L. W., Josse, B., Lee, Y. H., MacKenzie, I. A., Nagashima, T., Plummer, D. A., Righi, M., Rumbold, S. T., Skeie, R. B., Shindell, D. T., Strode, S. A., Sudo, K., Szopa, S., and Zeng, G.: Preindustrial to end 21st century projections of tropospheric ozone from the Atmospheric Chemistry and Climate Model Intercomparison Project (ACCMIP), Atmos. Chem. Phys., 13, 2063 2090, https://doi.org/10.5194/acp-13-2063-2013, 2013. 
Zachariasse, M., van Velthoven, P. F. J., Smit, H. G. J., Lelieveld, J., Mandal, T. K., and Kelder, H.: Influence of stratosphere troposphere exchange over the tropical Indian Ocean during the winter monsoon, J. Geophys. Res., 105, 15403-15416, 2000.

Zahn, A., Brenninkmeyer, C. A. M., Asman, W. A. H., Crutzen, P. J., Heinrich, G., Fischer, H., Cuijpers, J. W. M., and van Velthoven, P. F. J.: Budgets of $\mathrm{O}_{3}$ and $\mathrm{CO}$ in the upper troposphere: CARIBIC passenger aircraft results 1997-2001, J. Geophys. Res., 107, 4337, 13 pp., https://doi.org/10.1029/2001JD001529, 2002.
Zanis, P., Gerasopoulos, E., Priller, A., Schnabel, C., Stohl, A., Zerefos, C. S., Gäggeler, H. W., Tobler, L., Kubik, P. W., Kanter, H. J., Scheel, H. E., Luterbacher, J., and Berger, M.: An estimate of the impact of Stratosphere-to-Troposphere Transport (STT) on the lower free tropospheric ozone over the Alps using ${ }^{10} \mathrm{Be}$ and ${ }^{7} \mathrm{Be}$ measurements, J. Geophys. Res., 108, 8520, 9 pp., https://doi.org/10.1029/2002JD002604, 2003a.

Zanis, P., Trickl, T., Stohl, A., Wernli, H., Cooper, O., Zerefos, C., Gaeggeler, H., Schnabel, C., Tobler, L., Kubik, P. W., Priller, A., Scheel, H. E., Kanter, H. J., Cristofanelli, P., Forster, C., James, P., Gerasopoulos, E., Delcloo, A., Papayannis, A., and Claude, H.: Forecast, observation and modelling of a deep stratospheric intrusion event over Europe, Atmos. Chem. Phys., 3, 763-777, https://doi.org/10.5194/acp-3-763-2003, 2003b. 